Research article

urn:1sid:zoobank.org:pub:B4DDC9C7-69F4-40D1-A424-27D04331D1F8

\title{
Revision of the genus Cobbionema Filipjev, 1922 (Nematoda, Chromadorida, Selachinematidae)
}

\author{
Mohammed AHMED ${ }^{1, *}$, Sven BOSTRÖM ${ }^{2}$ \& Oleksandr HOLOVACHOV ${ }^{3}$ \\ ${ }^{1,2,3}$ Department of Zoology, Swedish Museum of Natural History, Box 50007, \\ SE-104 05 Stockholm, Sweden. \\ *Corresponding author: mohammed.ahmed@nrm.se \\ ${ }^{2}$ Email: Sven.Bostrom@nrm.se \\ ${ }^{3}$ Email: Oleksandr.Holovachov@nrm.se \\ ${ }^{1}$ urn:1sid:zoobank.org:author:C6B054C8-6794-445F-8483-177FB3853954 \\ ${ }^{2}$ urn:lsid:zoobank.org:author:528300CC-D0F0-4097-9631-6C5F75922799 \\ ${ }^{3}$ urn:lsid:zoobank.org:author:89D30ED8-CFD2-42EF-B962-30A13F97D203
}

\begin{abstract}
This paper reports on the genus Cobbionema Filipjev, 1922 in Sweden with the description of four species and a revision of the genus. Cobbionema acrocerca Filipjev, 1922 is relatively small in size, with a tail that has a conical proximal and a digitate distal section. Cobbionema cylindrolaimoides Schuurmans Stekhoven, 1950 is similar to $C$. acrocerca in most characters except having a larger body size and heavily cuticularized mandibles. Cobbionema brevispicula sp. nov. is characterised by short spicules and a conoid tail. Cobbionema acuminata sp. nov. is characterised by a long two-part spicule, a conical tail and three (one mid dorsal and two ventrosublateral) sharply pointed tines in the anterior chamber of the stoma that are located more anterior than in all the other species. We also present a molecular phylogeny of the family based on the nearly full-length 18S and the D2-D3 expansion segment of the 28S rRNA genes. Maximum Likelihood and Bayesian trees inferred from both genes strongly support a clade that included Cobbionema, Demonema Cobb, 1894 and Halichoanolaimus de Man, 1888 and another clade with Gammanema Cobb, 1920 and Latronema Wieser, 1954 nested together. None of the trees supported the monophyly of the subfamilies Choniolaiminae and Selachinematinae.
\end{abstract}

Keywords. West coast of Sweden, marine nematodes, predatory, stoma, phylogeny.

Ahmed M., Boström S. \& Holovachov O. 2020. Revision of the genus Cobbionema Filipjev, 1922 (Nematoda, Chromadorida, Selachinematidae). European Journal of Taxonomy 702: 1-34.

https://doi.org/10.5852/ejt.2020.702

\section{Introduction}

The family Selachinematidae Cobb, 1915 is a group of predatory marine nematodes characterised by, among other features, annulated or striated cuticle with transverse rows of dots and a two-chambered buccal cavity with a complex structure (Tchesunov 2014). The family has two subfamilies, Choniolaiminae Schuurmans Stekhoven \& Adam, 1931 and Selachinematinae Cobb, 1915, which together hold the 
13 genera described so far (Leduc 2013; Tchesunov 2014). Seven species of this family had previously been reported in Sweden (https://dyntaxa.se/Taxon/Info/2000413).

The genus Cobbionema was first erected by Filipjev (1922) to accommodate Cobbionema acrocerca Filipjev, 1922, which was described based on female specimens. The genus is classified within the subfamily Choniolaiminae for having well-developed anterior and posterior buccal chambers. Within the family Selachinematidae, Choniolaimus Ditlevsen, 1918 is one of the genera with the closest resemblance to Cobbionema (Gerlach 1964). The two can be distinguished on the basis of the presence of an anterior and a posterior pharyngeal bulb. In Choniolaimus, the pharynx has a distinct anterior and posterior bulb whereas in Cobbionema, only the anterior bulb is present. In terms of the stoma structure, Cobbionema closely resembles Halichoanolaimus de Man, 1888, but the two can be differentiated by the length of the cephalic sensilla as well as the shape of the spicules. The second species to be included in this genus was Cobbionema cylindrolaimoides which according to the author (Schuurmans Stekhoven 1950) differs from C. acrocerca in having a more cuticularized wall in the posterior chamber of the buccal cavity. Gerlach (1964) did not accept this distinction and therefore considered them possible synonyms, even though a detailed argument to support this action was lacking. The two species were, however, kept as separate species by Gerlach \& Riemann (1973). Cobbionema capense was later described by Furstenberg \& Heyns (1987), and this species was distinguished from C. acrocerca and C. cylindrolaimoides in having a moderately cuticularized posterior chamber of the buccal cavity as well as having teeth ridges. The description of $C$. trigamma by Leduc (2013) was the first species description within this genus to include male specimens. This species was separated from C. acrocerca based on features of the mandibles in the posterior buccal cavity and from C. capense based on the differences in the type and orientation of their buccal armament.

Here, we describe two new species of Cobbionema with remarks on the genus and its relationship with other genera within Selachinematidae. We also present an analysis of the phylogeny of the family based on nearly full-length of the $18 \mathrm{~S}$ and the D2-D3 expansion segments of the 28S ribosomal RNA sequences, by combining publicly available data and newly generated sequences.

\section{Material and methods}

\section{Sampling}

Bottom sediment samples were collected in several locations in the southern part of the Skagerrak and in Gullmarn Fjord off the west coast of Sweden. All samples were collected with a bottom dredge (Waren's dredge) or box corer and further sieved in the laboratory before fixation. Nematodes were extracted from samples using a decanting and sieving method (smallest mesh sizes: $45 \mu \mathrm{m}$ or $70 \mu \mathrm{m}$ ). Freshwater was used during sieving to induce an osmotic shock in nematodes inducing their detachment from the substrate. Material retained on the sieves was immediately fixed in a $4 \%$ formaldehyde solution or in $95 \%$ ethanol. For light microscopy, specimens were transferred to pure glycerine using Seinhorst's (1959) rapid method as modified by De Grisse (1969).

For SEM, specimens were post-fixed in $1 \%$ osmium tetroxide $\left(\mathrm{OsO}_{4}\right)$ and transferred to pure acetone through an acetone/distilled water series. Specimens were critical point dried in liquid $\mathrm{CO}_{2}$, mounted on stubs, gold-plated under vacuum to a thickness of $200 \AA$ in an Agar High Resolution Sputter Coater Model 20, and examined in a Hitachi S-4300 SEM at an accelerating voltage of $10 \mathrm{kV}$.

Permanent nematode mounts on glass slides were prepared using the paraffin wax ring method. All curved structures were measured along the curved median line. Measurements in all tables are presented in $\mu \mathrm{m}$ as mean and (range) where appropriate. Terminology follows Maggenti (2005). Abbreviations are according to Hunt \& Palomares-Ruis (2012). Other terminologies specific to this revision are also defined on Fig. 1. Specimens are deposited in the invertebrate collection of the Department of Zoology, Swedish Museum of Natural History, Stockholm, Sweden (SMNH). 


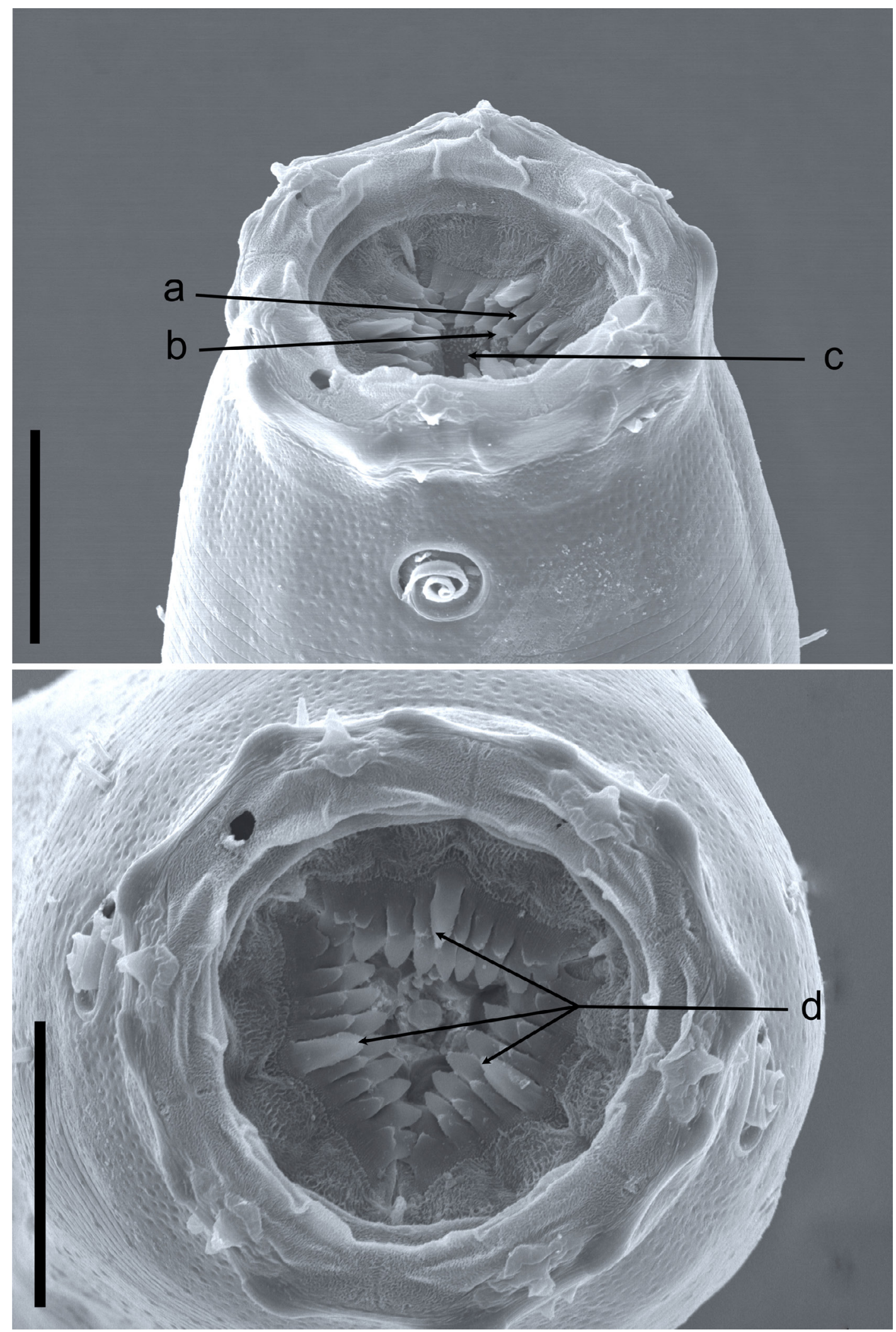

Fig. 1. Halichoanolaimus robustus (Bastian, 1865). Scanning electron micrographs. Abbreviations: $\mathrm{a}=$ anterior row of pointed projections; $\mathrm{b}=$ posterior row of pointed projections; $\mathrm{c}=$ field of distinct denticles; $d=$ the three tines (one middorsal, two ventrosublateral). Scale bar $=25 \mu \mathrm{m}$. 


\section{DNA extraction and amplification}

DNA extraction was performed on Choniolaimus papillatus Ditlevsen, 1918, Cobbionema sp. (likely another undescribed species), Demonema rapax Cobb, 1894, Gammanema rapax (Ssaweljev, 1912), Gammanema rapax sensu Platt \& Warwick 1988, Halichoanolaimus dolichurus Ssaweljev, 1912, H. norvegicus Allgén, 1940 and Latronema sp. (likely an undescribed species) using the Qiagen QiAmp DNA Micro kit (Qiagen, Sollentuna, Sweden). Individual nematodes (either freshly collected or stored in $95 \%$ ethanol at $-20^{\circ} \mathrm{C}$ ) were each placed in $1.5 \mathrm{ml}$ microcentrifuge tubes containing $20 \mu \mathrm{l}$ buffer ATL (Qiagen, Sweden) and stored at $-20^{\circ} \mathrm{C}$ until all samples were ready for extraction. During the extraction, $160 \mu 1$ of buffer ATL was added to each sample. This was followed by the addition of $20 \mu 1$ proteinase K, vortexing and incubation in an incubating microplate shaker (VWR, Spånga, Sweden) at $56^{\circ} \mathrm{C}$ and $300 \mathrm{rpm}$ overnight. The lysed samples were further processed to obtain pure DNA following the manufacturer's instructions for genomic DNA extraction using the Qiagen QiAmp DNA Micro kit.

Two regions of the rRNA gene, the nearly full-length of the 18S and the D2-D3 expansion segment of $28 \mathrm{~S}$, were amplified. The approximately $1800 \mathrm{bp}$ region of the $18 \mathrm{~S}$ rRNA gene was amplified as two overlapping fragments using the primer sets $988 \mathrm{~F}-1912 \mathrm{R}$ for the first fragment and $1813 \mathrm{~F}-2646 \mathrm{R}$ for the second fragment (Holterman et al. 2006). Polymerase chain reaction (PCR) for both fragments was performed in $25 \mu \mathrm{l}$ reaction mix using Illustra Hot Start Mix RTG $0.2 \mathrm{ml}$ reaction kit (GE Healthcare Life Sciences, Sweden). The reaction mix consisted of $1 \mu 1(0.4 \mu \mathrm{M})$ of each primer, $2 \mu 1$ template DNA and $21 \mu \mathrm{l}$ nuclease-free water. The reaction conditions were $5 \mathrm{~min}$ at $95^{\circ} \mathrm{C} ; 5$ cycles of $\left(30 \mathrm{sec}\right.$ at $94^{\circ} \mathrm{C}$, $30 \mathrm{sec}$ at $45^{\circ} \mathrm{C}$ and $30 \mathrm{sec}$ at $\left.72^{\circ} \mathrm{C}\right) ; 35$ cycles of $\left(30 \mathrm{sec}\right.$ at $94^{\circ} \mathrm{C}, 30 \mathrm{sec}$ at $54^{\circ} \mathrm{C}$ and $30 \mathrm{sec}$ at $\left.72^{\circ} \mathrm{C}\right)$; and a final extension for $5 \mathrm{~min}$ at $72^{\circ} \mathrm{C}$. The D2-D3 segment of the $28 \mathrm{~S}$ rRNA gene was amplified using the primers D2Af and D3Br (Nunn 1992). PCR was performed in $25 \mu 1$ reaction mix containing $1 \mu 1$ $(0.4 \mu \mathrm{M})$ of each primer, $2 \mu 1$ template DNA and $21 \mu 1$ nuclease-free water. The PCR conditions were $4 \mathrm{~min}$ at $94^{\circ} \mathrm{C} ; 35 \mathrm{cycles}$ of $\left(94^{\circ} \mathrm{C}\right.$ for $60 \mathrm{sec}, 54^{\circ} \mathrm{C}$ for $90 \mathrm{sec}$ and $72^{\circ} \mathrm{C}$ for $\left.2 \mathrm{~min}\right)$; final extension for $10 \mathrm{~min}$ at $72^{\circ} \mathrm{C}$. Enzymatic PCR clean-up was performed on the PCR product using Exonuclease I and Shrimp Alkaline Phosphatase (New England Biolabs, MA, USA). The purified PCR products were sent out to Macrogen Europe B.V. (Amsterdam, the Netherlands) for sequencing. Each amplicon was sequenced in both directions using the forward and reverse PCR primers.

The trace files of the individual sequences were visualized inside BioEdit (Hall 1999) and trimmed to high quality. The trimmed forward and reverse sequences were then assembled using Fragment Merger online tool (Bell \& Kramvis 2013). The two fragments of the 18S rRNA gene were also assembled into contigs using the Fragment Merger online tool.

The nuclear ribosomal 18S and D2-D3 region of the 28S rRNA sequences were deposited in GenBank as follows. 18S rRNA accession numbers: MN786721-MN786722 (Choniolaimus papillatus), MN786723 (Cobbionema sp.), MN786724 (Demonema rapax), MN786725-MN786728, MN786730, MN786732 (Gammanema rapax), MN786729, MN786731 (Gammanema rapax sensu Platt \& Warwick 1988), MN786733-MN786736 (Halichoanolaimus dolichurus), MN786737-MN786738 (Halichoanolaimus norvegicus), MN786739-MN786741 (Latronema sp.); D2-D3 of 28S rRNA accession numbers: MN786742-MN786745 (Choniolaimus papillatus), MN786746 (Cobbionema sp.), MN786747MN786748 (Demonema rapax), MN786749-MN786752, MN786754, MN786756 (Gammanema rapax), MN786753, MN786755 (Gammanema rapax sensu Platt \& Warwick 1988), MN786757MN786760 (Halichoanolaimus dolichurus), MN786761-MN786763 (Halichoanolaimus norvegicus), MN786764-MN786766 (Latronema sp.).

\section{Phylogenetic analysis}

Alignments from Holovachov et al. (2017) for 18S rRNA gene and Holovachov et al. (2015) for D2D3 segment of the 28S rRNA gene were used as templates for alignment and annotation of the recently 
published and newly generated sequences of Selachinematidae nematodes (see above). Secondary structure annotation was manually added to all non-annotated sequences using the JAVA-based editor 4SALE (Seibel et al. 2006), and all sequences were manually aligned to maximise apparent positional homology of nucleotides. Phylogenetic trees were built using RAxML ver. HPC2 (Stamatakis 2014) via the CIPRES portal (Miller et al. 2010) for the Maximum Likelihood inference of the partitioned dataset. The GTR nucleotide substitution model was used for non-paired sites, whereas the RNA7A (Higgs 2000) substitution model was used for paired sites. Bootstrap ML analysis was performed using the rapid bootstrapping option with 1000 iterations. For the Bayesian inference, PHASE 3 (Gowri-Shankar \& Jow 2006) was used. The nucleotide substitution model REV GAMMA was used for non-paired sites and RNA16A paired-site substitution model for the paired sites (stems, hairpins) of the rRNA.

Sequence deposited in GenBank (Benson et al. 2018) under the accession number FJ040468 and identified as Synonchiella sp. belongs to Halichoanolaimus robustus (Bastian, 1865) de Man 1886, based on a reinvestigation of the images of the voucher specimen used for sequencing.

\section{Results}

\section{Taxonomy}

Phylum Nematoda Potts, 1932

Class Chromadorea Inglis, 1983

Order Chromadorida Chitwood, 1933

Family Selachinematidae Cobb 1915

Genus Cobbionema Filipjev, 1922

\section{Type species}

Cobbionema acrocerca Filipjev, 1922

\section{Diagnosis}

\section{Adult characters}

Body cylindrical, tapering slightly towards both extremities. Cuticle with fine transverse striation, with transverse rows of subcuticular dots, one row per annule. Lateral differentiation where punctations are irregularly spaced and further apart (cf. Bendiella Leduc, 2013) is absent. Lateral alae present in some species, shaped as single band of raised smooth cuticle. Somatic setae scattered along the body. Cephalic region narrower from the level of the base of the anterior chamber of the stoma. Inner labial sensilla indistinct. Outer labial sensilla small papilliform, located on the periphery of labial region. Cephalic sensilla setiform. Amphideal fovea lateral or ventrosublateral, large, sexually dimorphic in size, multispiral with circular outline. Anterior chamber of buccal cavity barrel-shaped or cylindrical in C. capense and C. trigamma, with 12 cuticularized rhabdions or six in C. trigamma, each with two pairs of large, pointed projections at posterior extremity. These projections are arranged in two horizontal rows, appearing from an en face view as two transverse circles of denticles separating the stoma into anterior and posterior chamber. Three (one middorsal and two ventrosublateral) prominent and sharply pointed tines (slender pointed projections, cf. Maggenti 2005) located a short distance in front of the anterior circle of denticles. Posterior buccal chamber cone-shaped, widest at (posterior or anterior) extremity (depending on the state of stomatal musculature), with strongly cuticularized Y-shaped mandibles; anterior branches of each mandible with denticles on its inner surface; posterior 'stem' of each mandible with strongly or weakly developed basal (submedian) knobs. The stoma structure of all studied specimens generally resembles that of Halichoanolaimus both in the arrangement of pointed projections in the anterior chamber of the stoma and the shape of the mandibles in the posterior chamber (Fig. 1). Anterior buccal chamber surrounded by strongly developed sphincter muscle. Pharynx muscularised, 
with conspicuous anterior swelling surrounding the base of buccal cavity and widens posteriorly but not forming true posterior bulb. Cardia small, with cuticularized lumen. Tail straight or curved ventrally, conical in shape or with distinct conical proximal portion and a digitate (= subcylindrical) distal end. Caudal glands present, opening via a common spinneret, caudal gland cells/bodies at level with posterior part of intestine, anterior to cloaca or extending anterior to the posteriormost end of the intestine.

\section{Male}

Reproductive system diorchic, with outstretched anterior testis and reflexed posterior testis. Anterior and posterior testis can lie on either left or right side of intestine. Spicules paired and symmetrical, elongate, consisting of two sections separated by a constriction, nearly straight, with rounded manubrium, subcylindrical shaft, or short with bifid tips. Gubernaculum reduced only to two sublateral crura, arcuate conoid in shape, flanking distal part of spicules. Precloacal supplements setose or papilloid, midventral and range in number from one to five.

\section{Female}

Reproductive system didelphic, amphidelphic, ovary branches reflexed antidromously. Anterior ovary on left of intestine, posterior ovary on right side of intestine or vice versa. Vagina straight, without cuticularizations, surrounded by single sphincter muscle. Vulva midventral, a transverse slit. Rectum absent.

\section{Remarks}

Gerlach (1964) could not resolve the relationship of this genus with the other members of Selachinematidae due to the limited understanding of its buccal structure at that time. The descriptions of $C$. capense and C. trigamma have contributed useful insights into the nature of the buccal cavity of this genus. In spite of this, some differences in terminologies used to describe, possibly the same, features in the buccal cavity of these species need clarification. For example, pointed projections in C. trigamma and denticles in C. capense may refer to the same character; which could also be the same feature Schuurmans Stekhoven (1950) described as rows of denticular corpuscles. Also, the three chitinous hooks mentioned in the description of $C$. acrocerca could be the same as the teeth that were referred to in the description of $C$. capense. Moreover, an examination of the Swedish populations identified as $C$. acrocerca and $C$. cylindrolaimoides revealed that some of the characters described as unique to some species were actually found in others. For example, the Y-shaped rhabdions found in C. trigamma were also observed in all species of Cobbionema that were examined in this study and are very similar to the ones found in most species of Halichoanolaimus. In the descriptions of C. acrocerca and $C$. capense, a sphincter muscle around the anterior and part of the posterior chambers of the buccal cavity were described. This character has also been observed in all populations of C. acrocerca and C. cylindrolaimoides as well as the two new species described here, and depicted in Leduc (2013: fig. 10). This character has, however, not been observed in other genera of the family. There is therefore a possibility that this feature could be an apomorphic character which separates this genus from other genera within Selachinematidae.

\section{Relationships}

Cobbionema differs from all other genera of Selachinematidae in having a sphincter muscle around the anterior buccal chamber. Species of Cobbionema are similar to Halichoanolaimus in the rows of pointed projections at the intersection between the two buccal chambers as well as the three tines (one middorsal and two ventrosublateral) anterior to these two rows of pointed projections. In H. robustus, for example, the tail shape closely resembles that of some Cobbionema species. However, Cobbionema can be distinguished from Halichoanolaimus by the cephalic sensilla being setiform and not papilliform. Cobbionema can also be distinguished from Choniolaimus by the absence of terminal pharyngeal bulb 
and shape of precloacal supplements. Table 1 summarizes some of the differentiating features between Cobbionema and other genera included in Selachinematidae.

\section{Valid species}

Cobbionema acrocerca Filipjev, 1922

Cobbionema acuminata sp. nov.

Cobbionema brevispicula sp. nov.

Cobbionema capense Furstenberg \& Heyns, 1987

Cobbionema cylindrolaimoides Schuurmans Stekhoven, 1950

Cobbionema trigamma Leduc, 2013

Cobbionema acrocerca Filipjev, 1922

Figs 2-3, Table 2

\section{Diagnosis}

Cobbionema acrocerca is particularly characterised by $0.59-0.86 \mathrm{~mm}$ long body; lateral alae present; body pores arranged on either sides of lateral alae; cephalic sensilla equal to $0.3-0.6$ labial region diameters in length; amphideal fovea sexually dimorphic, with 4.25-5.25 turns in males and 3.25-3.75 turns in females; two rows of pointed projections and a third row with three prominent sharply pointed tines in the stoma, rows of projections close to one another longitudinally; spicules consisting of two sections, $50-58 \mu \mathrm{m}$ long; single precloacal papilliform sensillum; tail with conoid proximal and digitate distal section.

\section{Material examined}

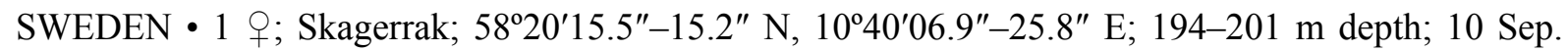
2012; "Inventering Bratten" leg.; soft bottom; SMNH-179216 • 1 o'; Skagerrak; 58 19'15.6"-20.9" N, $10^{\circ} 29^{\prime} 33.5^{\prime \prime}-34.0^{\prime \prime}$ E; 352-374 m depth; 10 Sep. 2012; "Inventering Bratten" leg.; soft bottom; SMNH-

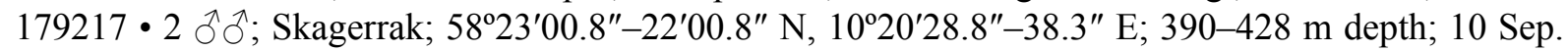

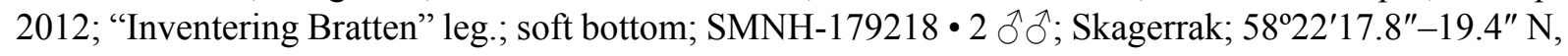
10²3'50.8"-24'03.2" E; 351-387 m depth; 10 Sep. 2012; "Inventering Bratten" leg.; soft bottom; SMNH-179219 • 1 ơ; Skagerrak; 58 28'28.0"-31.1" N, 10³3'19.1"-23.8" E; 221-260 m depth; 11 Sep.

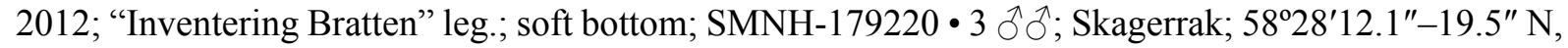
10³7'01.1"-07.1" E; 180-216 m depth; 11 Sep. 2012; "Inventering Bratten" leg.; soft bottom; SMNH179221, SMNH179222 • 1 ㄱ, 2 우; Skagerrak; 58 34'21.3"-16.6" N, 10³8'11.2"-29.4" E; 139153 m depth; 12 Sep. 2012; "Inventering Bratten" leg.; soft bottom; SMNH-179223 • 1 \%; Skagerrak; 58 27'36.7"-43.3" N, 10³2'52.0"-59.4" E; 232-240 m depth; 12 Sep. 2012; “Inventering Bratten" leg.; soft bottom; SMNH-179224.

\section{Description}

\section{Adult characters}

Body cylindrical, tapering slightly towards both extremities. Cuticle with transverse rows of dots, no lateral differentiation. Lateral alae present, single band of smooth cuticle (Fig. 3F) starting at level with basal pharyngeal bulb and ending anterior to anus/cloaca. Body pores present, starting at level with anterior part of pharynx and extending to tail region, located sublaterally on either dorsal or ventral side of lateral alae, irregularly spaced. Somatic setae scattered along the body. Labial region bluntly-rounded, not set-off. Cephalic region of males and females narrower from the level of the base of the anterior chamber of the stoma. Six equal lips surrounding mouth opening. Inner labial sensilla indistinct. Outer labial sensilla small papilliform, located on the periphery of labial region. Cephalic sensilla setiform, equal to 0.3-0.6 labial region diameters in length, located at the same level as outer labial sensilla. 
Table 1 (continued on the next page). Comparison between all genera of Selachinematidae Cobb, 1915 based on key morphological characteristics.

\begin{tabular}{|c|c|c|c|c|c|c|}
\hline Characters & $\begin{array}{c}\text { Bendiella } \\
\text { Leduc, } 2013\end{array}$ & $\begin{array}{c}\text { Choanolaimus } \\
\text { de Man, } 1880\end{array}$ & $\begin{array}{c}\text { Choniolaimus } \\
\text { Ditlevsen, } 1918\end{array}$ & $\begin{array}{c}\text { Cobbionema } \\
\text { Filipjev, } 1922\end{array}$ & $\begin{array}{c}\text { Gammanema } \\
\text { Cobb, } 1920\end{array}$ & $\begin{array}{c}\text { Halichoanolaimus } \\
\text { de Man, } 1886\end{array}$ \\
\hline $\begin{array}{l}\text { Cuticular } \\
\text { ornamentations }\end{array}$ & $\begin{array}{l}\text { Transverse } \\
\text { rows of dots }\end{array}$ & $\begin{array}{l}\text { Transverse } \\
\text { rows of dots }\end{array}$ & $\begin{array}{l}\text { Transverse } \\
\text { rows of dots }\end{array}$ & $\begin{array}{l}\text { Transverse } \\
\text { rows of dots }\end{array}$ & $\begin{array}{l}\text { Transverse } \\
\text { rows of dots }\end{array}$ & $\begin{array}{c}\text { Transverse rows of } \\
\text { dots }\end{array}$ \\
\hline $\begin{array}{l}\text { Lateral } \\
\text { differentiation }\end{array}$ & $\begin{array}{l}\text { Dots wider } \\
\text { apart }\end{array}$ & $\begin{array}{l}\text { Dots wider } \\
\text { apart }\end{array}$ & Absent & $\begin{array}{l}\text { Absent or with } \\
\text { single ala }\end{array}$ & Absent & Absent \\
\hline $\begin{array}{l}\text { Inner labial } \\
\text { sensilla }\end{array}$ & Papilliform & Papilliform & Papilliform & Papilliform & $\begin{array}{l}\text { Papilliform/ } \\
\text { Setiform }\end{array}$ & Papilliform \\
\hline $\begin{array}{l}\text { Outer labial } \\
\text { sensilla }\end{array}$ & Papilliform & Papilliform & Setiform & $\begin{array}{l}\text { Papilliform/ } \\
\text { Setiform }\end{array}$ & Setiform & Papilliform \\
\hline $\begin{array}{l}\text { Cephalic } \\
\text { sensilla }\end{array}$ & Papilliform & Papilliform & Setiform & Setiform & Setiform & Papilliform \\
\hline $\begin{array}{l}\text { Sphincter } \\
\text { muscle around } \\
\text { stoma }\end{array}$ & Absent & Absent & Absent & Present & Absent & Absent \\
\hline $\begin{array}{l}\text { Anterior } \\
\text { pharyngeal } \\
\text { bulb }\end{array}$ & Absent & Present & Present & Present & Absent & Absent \\
\hline $\begin{array}{l}\text { Posterior } \\
\text { pharyngeal } \\
\text { bulb }\end{array}$ & Absent & Absent & Present & Absent & Absent & Absent \\
\hline $\begin{array}{l}\text { Precloacal } \\
\text { supplements }\end{array}$ & Absent & Papilloid & Cup-shaped & $\begin{array}{l}\text { Papilloid or } \\
\text { setose }\end{array}$ & Cup-shaped & Setose \\
\hline Tail shape & Elongated & $\begin{array}{l}\text { Short conical, } \\
\text { almost } \\
\text { rounded }\end{array}$ & Conical & $\begin{array}{c}\text { Conical } \\
\text { proximally, } \\
\text { subcylindrical } \\
\text { distally }\end{array}$ & Conical & $\begin{array}{c}\text { Conical proximally, } \\
\text { subcylindrical } \\
\text { distally }\end{array}$ \\
\hline
\end{tabular}

Amphideal fovea ventrosublateral, large, sexually dimorphic in size, multispiral with $4.25-5.25$ turns in males and 3.25-3.75 turns in females, with circular outline, equal to about $0.5-0.6$ of the corresponding body diameter in males and 0.3 in females. Five to seven pairs of cervical setae present, located posterior to amphid in subventral, ventrosublateral, subdorsal and dorsosublateral positions (cervical setae can be distinguished from somatic sensilla in having larger size and regular arrangement in pairs between amphid and nerve ring level). Buccal cavity voluminous, divided into anterior and posterior chambers. Anterior chamber of buccal cavity barrel-shaped, with 12 cuticularized rhabdions, each with two pairs of large, pointed projections at its posterior extremity. These projections are arranged in two horizontal rows, appearing from an en face view as two circles of denticles separating the stoma into anterior and posterior chamber. Three (one middorsal and two ventrosublateral) prominent and sharply pointed tines located a short distance in front of anterior circle of denticles. Posterior buccal chamber coneshaped, widest at (posterior or anterior) extremity (depending on the state of stomatal musculature), with three strongly cuticularized Y-shaped mandibles; anterior branches of each mandible rather short and acute; posterior "stem" of each mandible enlarged but without basal (submedian) knobs (Fig. 3A-B). Anterior buccal chamber surrounded by strongly developed sphincter muscle. Each mandible is also supported by a strong longitudinal and tangential musculature, altogether appearing as a muscular bulb. Pharynx muscularised, with developed glandular tissue throughout its entire length; with conspicuous 
Table 1 (continued). Comparison between all genera of Selachinematidae Cobb, 1915 based on key morphological characteristics.

\begin{tabular}{|c|c|c|c|c|c|c|}
\hline $\begin{array}{c}\text { Kosswigonema } \\
\text { Gerlach, } 1964\end{array}$ & $\begin{array}{c}\text { Latronema } \\
\text { Wieser, } 1954\end{array}$ & $\begin{array}{c}\text { Cheironchus } \\
\text { Cobb, } 1917\end{array}$ & $\begin{array}{l}\text { Demonema } \\
\text { Cobb, } 1894\end{array}$ & $\begin{array}{c}\text { Pseudocheironchus } \\
\text { Leduc, } 2013\end{array}$ & $\begin{array}{c}\text { Synonchiella } \\
\text { Cobb, } 1933\end{array}$ & $\begin{array}{c}\text { Synonchium } \\
\text { Cobb, } 1920\end{array}$ \\
\hline $\begin{array}{c}\text { Transverse rows } \\
\text { of dots }\end{array}$ & $\begin{array}{l}\text { Transverse } \\
\text { rows of } \\
\text { dots and } \\
\text { longitudinal } \\
\text { ridges }\end{array}$ & $\begin{array}{l}\text { Transverse } \\
\text { rows of dots }\end{array}$ & $\begin{array}{l}\text { Transverse } \\
\text { rows of dots }\end{array}$ & $\begin{array}{c}\text { Transverse rows of } \\
\text { dots }\end{array}$ & $\begin{array}{l}\text { Transverse } \\
\text { rows of dots }\end{array}$ & $\begin{array}{l}\text { Transverse } \\
\text { rows of dots }\end{array}$ \\
\hline Absent & Absent & Absent & Absent & Absent & Absent & Absent \\
\hline Papilliform & Setiform & Papilliform & Papilliform & Papilliform & Papilliform & Papilliform \\
\hline Setiform & Setiform & Papilliform & Papilliform & Papilliform & Papilliform & Papilliform \\
\hline Setiform & Setiform & Setiform & Papilliform & Papilliform & Setiform & Papilliform \\
\hline Absent & Absent & Absent & Absent & Absent & Absent & Absent \\
\hline Present & Absent & Present & Present & Present & Absent & Absent \\
\hline Absent & Absent & Present & Absent & Present & Absent & Absent \\
\hline Cup-shaped & Setose & Cup-shaped & Cup-shaped & Cup-shaped & Cup-shaped & Absent \\
\hline Conical & Conical & $\begin{array}{l}\text { Bluntly } \\
\text { conical }\end{array}$ & $\begin{array}{c}\text { Conical } \\
\text { proximally, } \\
\text { subcylindrical } \\
\text { distally }\end{array}$ & Rounded & $\begin{array}{c}\text { Conical, } \\
\text { distally } \\
\text { cylindrical } \\
\text { with clavate } \\
\text { terminus }\end{array}$ & $\begin{array}{c}\text { Short conical, } \\
\text { digitate }\end{array}$ \\
\hline
\end{tabular}

anterior swelling surrounding the base of buccal cavity; pharynx widens posteriorly but not forming true posterior bulb. Cardia small, with cuticularized lumen. Secretory-excretory system present, renette body located at level with pharyngo-intestinal junction, secretory-excretory pore located just posterior to nerve ring. Tail straight or ventrally curved, distinctly divided into conoid proximal and digitate distal sections. Caudal glands present, opening via a common spinneret, caudal gland cells/bodies may extend anterior to the posteriormost end of intestine.

\section{Male}

Reproductive system diorchic, with outstretched anterior testis and reflexed posterior testis, always on opposite sides of the intestine. Anterior testis on either left $(n=6)$ or right $(n=1)$ side of intestine, posterior testis on right $(\mathrm{n}=6)$ or left $(\mathrm{n}=1)$ side of intestine. Spicules paired and symmetrical, elongate, consisting of two sections, subcylindrical proximal section and conoid/fusiform distal section (Fig. $2 \mathrm{H}$ ), equal to 1.9-2.8 anal body diameters in length. Gubernaculum reduced to sublateral crura, arcuate conoid in shape, with central bend (Figs 2I, 3E), flanking distal part of spicules. Single midventral precloacal papilliform sensillum located $6 \mu \mathrm{m}$ from the cloacal opening. Further papilliform sensilla arranged in pairs subventrally and subdorsally anterior to cloaca and along tail. 

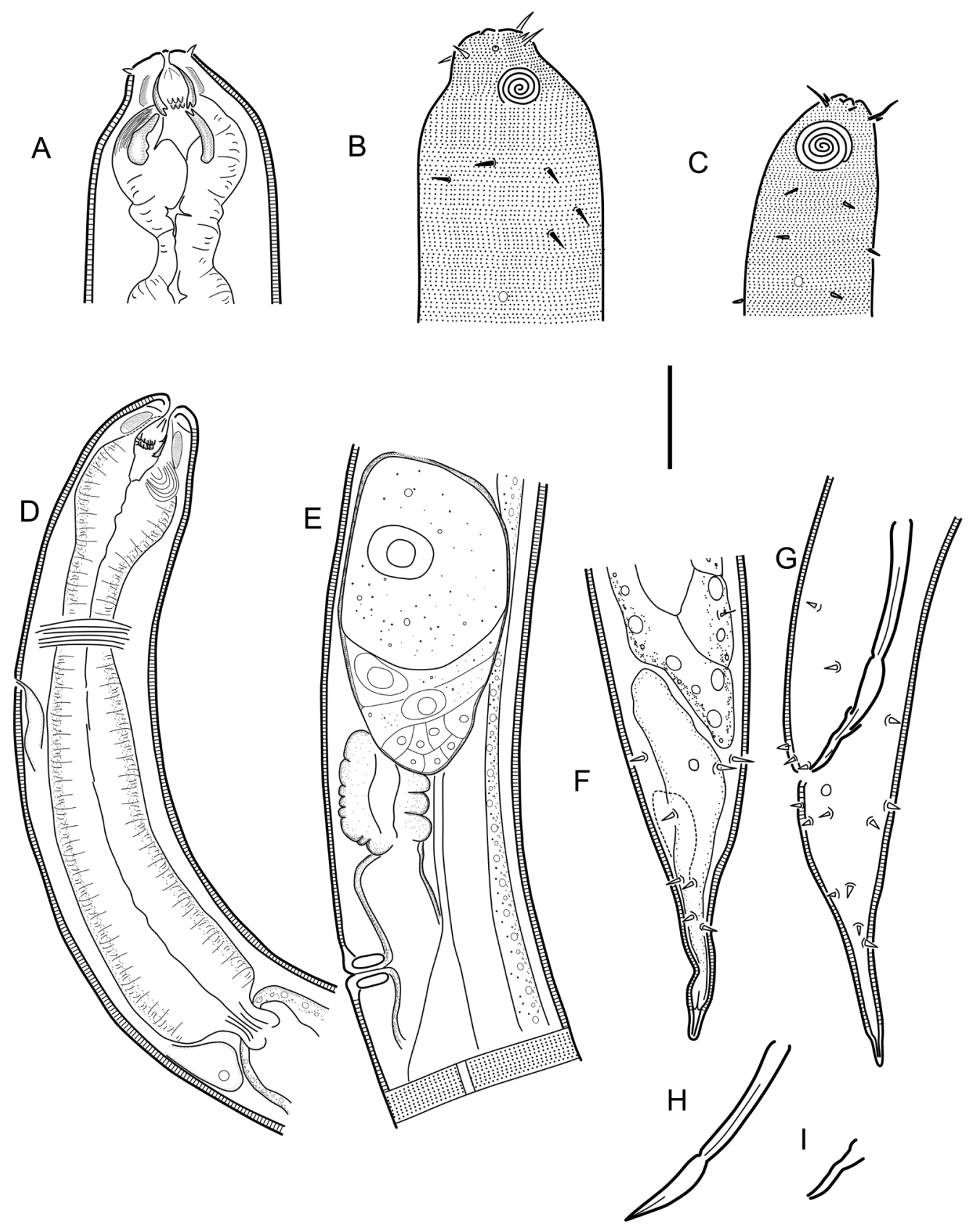

Fig. 2. Cobbionema acrocerca Filipjev, 1922. A. Female head region (ventral side to the right) (SMNH179223). B. Surface view of female head (ventral side to the right) (SMNH-179223). C. Surface view of male head (ventral side to the left) (SMNH-179217). D. Anterior part of male (ventral side to the left) (SMNH-179217). E. Female mid-body region showing anterior branch of the reproductive system and lateral ala (SMNH-179216). F. Female caudal region (SMNH-179216). G. Male caudal region (SMNH179217). H. Spicule. I. Crura. Scale bar $=20 \mu \mathrm{m}$. 


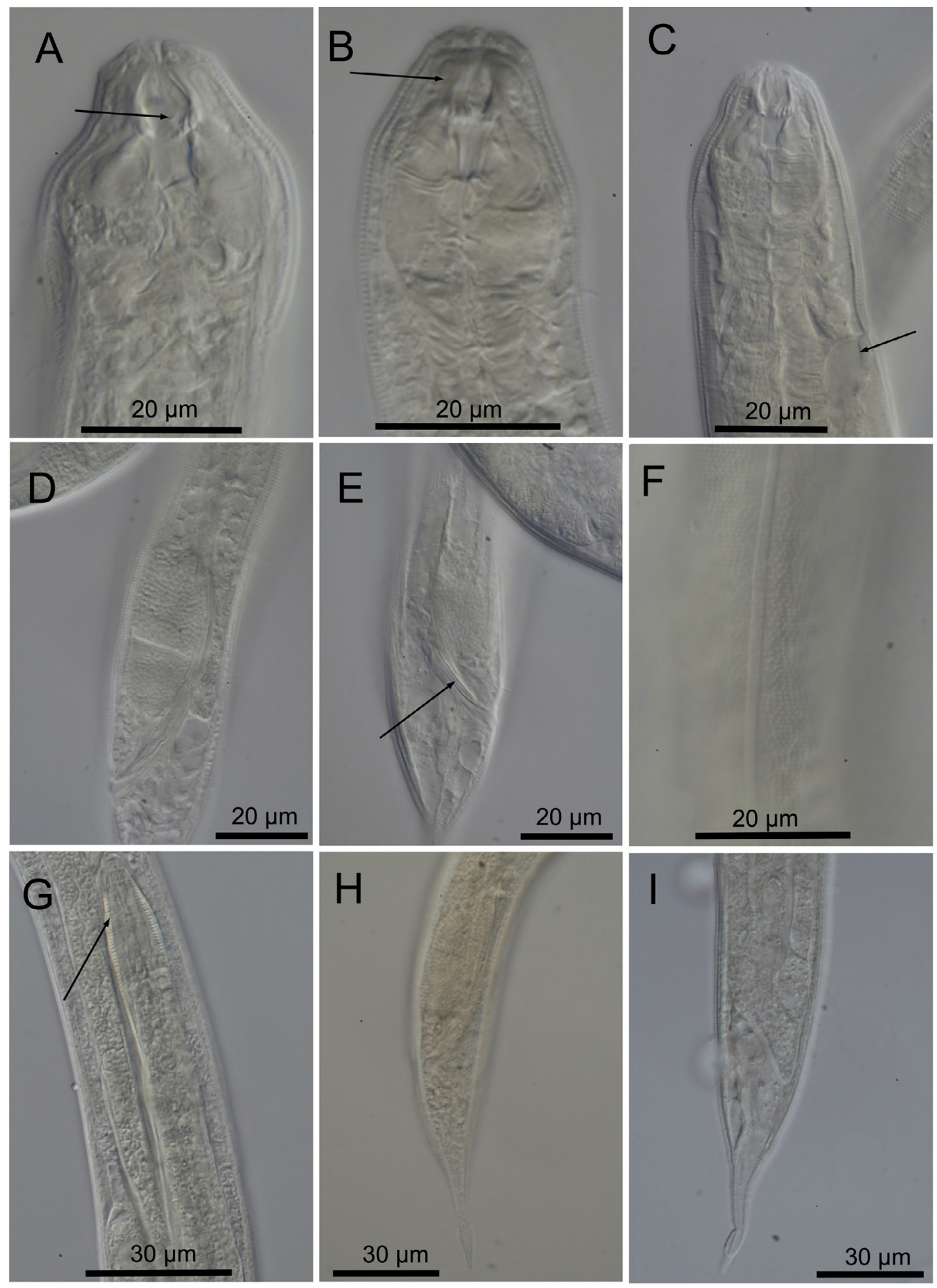

Fig. 3. Cobbionema acrocerca Filipjev, 1922. Light micrographs. A. Female stoma showing stoma armament, arrow pointing to the left ventrosublateral tine (SMNH-179217). B. Anterior part of a female with arrow pointing to the sphincter muscle surrounding the anterior stoma chamber (SMNH-179217). C. Anterior part of a female with arrow showing the ampulla of the secretory-excretory system (SMNH179218). D. Caudal region a male showing spicule. E. Caudal region of a male showing the crura (arrow) (SMNH-179218). F. Cuticle showing lateral ala (SMNH-179223). G. Nematode prey inside a female (arrow) (SMNH-179216). H. Male caudal region (SMNH-179217). I. Female caudal region (SMNH-179223). 


\section{Female}

Reproductive system didelphic, amphidelphic, ovary branches reflexed antidromously. Anterior ovary on either left $(n=2)$ or right $(n=2)$ side of intestine, posterior ovary on either right $(n=2)$ or left $(n=2)$ side of intestine. Oviducts with large cylindrical cells. Uterus thin-walled, filled with round spermatozoa in fertilized females. Vagina straight, without cuticularization, surrounded by single sphincter muscle. Vulva midventral, a transverse slit. Intra-uterine egg not seen. Rectum absent.

\section{Differential diagnosis}

The original description of Cobbionema acrocerca by Filipjev (1922) was based on several female specimens of which only one was measured. The Swedish population examined here resembles the type specimen in terms of body size and a number of body measurements (Table 2), having unremarkable mandibles in the posterior stoma and proximal part of the tail being conical in shape. Cobbionema acrocerca differs from C. cylindrolaimoides in having a smaller body (588-860 $\mu \mathrm{m}$ vs 1360 $1755 \mu \mathrm{m}$ in C. cylindrolaimoides), smaller spicules $(50-58 \mu \mathrm{m}$ vs $89-98 \mu \mathrm{m}$ in C. cylindrolaimoides), weakly cuticularized mandibles (vs strongly cuticularised), and different tail shape in females (with conoid vs dome-shaped proximal section).

Cobbionema acrocerca differs from all other species of Cobbionema, except $C$. cylindrolaimodes, in the morphology of the cuticle (lateral alae present in C. acrocerca vs absent in all except $C$. cylindrolaimoides). Cobbionema acrocerca can also be distinguished from holotype male of $C$. trigamma in having smaller body size $(592-666 \mu \mathrm{m}$ vs $1305 \mu \mathrm{m})$ and smaller spicules. In comparison with paratypes of $C$. trigamma, however, $C$. acrocerca only differs from $C$. trigamma in the morphology of the cuticle (lateral alae present in C. acrocerca vs absent in C. trigamma).

Cobbionema acrocerca can be distinguished from C. capense in the relative positions of cephalic and outer labial sensilla (outer labial sensilla more posterior to cephalic sensilla in $C$. capense vs cephalic sensilla at the same level as outer labial sensilla) as well as the cuticle morphology (lateral alae present in C. acrocerca vs absent in C. capense).

\section{Biology}

Gut content included undigested remains (spicules and gubernacula) or partially digested entire bodies of a variety of nematode species (Fig. 3G), including Chromadoridae Filipjev, 1917.

Cobbionema cylindrolaimoides Schuurmans Stekhoven, 1950

Figs 4-5, Table 2

\section{Diagnosis}

Cobbionema cylindrolaimoides is characterised by $1.36-1.76 \mathrm{~mm}$ long body; lateral alae present; body pores arranged on either sides of lateral alae; cephalic sensilla, equal to $0.3-0.5$ labial region diameters in length; amphideal fovea sexually dimorphic, with 3.5-4.25 turns in males and 3.25-3.5 turns in females; two rows of pointed projections and three prominent sharply pointed tines in the stoma, rows of projections close to one another longitudinally; spicules consisting of two sections, 89-98 $\mu \mathrm{m}$ long; single midventral precloacal papilliform sensillum; tail with conoid or dome shaped proximal and digitate distal section.

\section{Material examined}

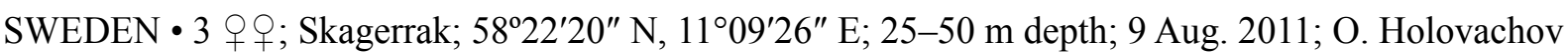

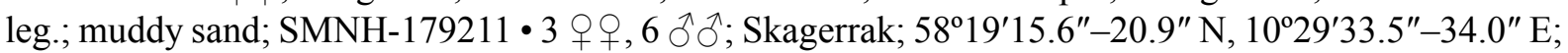

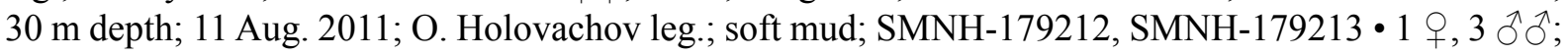
Skagerrak; 58¹9'15.6"-20.9" N, 10²9'33.5"-34.0" E; 30 m depth; 11 Aug. 2011; O. Holovachov leg.; soft mud; SMNH-179214, SMNH-179215. 


\section{Description}

\section{Adult characters}

Body cylindrical, tapering slightly towards both extremities. Cuticle with transverse rows of dots, without lateral differentiation. Lateral alae present, single band of smooth cuticle starting at level with basal pharyngeal bulb and ending anterior to anus/cloaca. Body pores present, starting at level with anterior part of pharynx and extending to tail region, located on either side of the lateral alae, irregularly spaced. Somatic setae scattered along the body. Labial region bluntly rounded, not set off. Depending on which muscles are constricted, cephalic region can be cylindrical or with a broad and shallow constriction at level with amphidial fovea. Six equal lips surrounding mouth opening. Inner labial sensilla indistinct. Outer labial sensilla small papilliform, located on the periphery of labial region. Cephalic sensilla setiform, equal to 0.3-0.5 labial region diameters in length, located at the same level as outer labial sensilla. Amphideal fovea ventrosublateral, large, sexually dimorphic in size, multispiral with 3.5-4.25 turns in males and 3.25-3.5 turns in females, with circular outline, equal to about $0.4-$ 0.5 of the corresponding body diameter in male and $0.2-0.3$ in female. Two to three pairs of cervical setae present, located posterior to amphid in ventrosublateral and dorsosublateral positions. Buccal cavity voluminous, divided into anterior and posterior chambers, partially everted in some specimens. Anterior chamber of buccal cavity barrel-shaped, with 12 cuticularized rhabdions, each with two pairs of large, pointed projections at posterior extremity. These projections are arranged in two horizontal rows, appearing from an en face view as two circles of denticles separating the stoma into anterior and posterior chamber. Three (one middorsal and two ventrosublateral) prominent and sharply pointed, almost setiform tines located a short distance in front of anterior circle of denticles. Posterior buccal chamber cone-shaped, widest at (posterior or anterior) extremity, or cylindrical (depending on the state of stomatal musculature), with three strongly cuticularized Y-shaped mandibles; anterior branches of each mandible broad triangular, with a field of distinct denticles; posterior 'stem' of each mandible with strongly developed basal (submedian) knobs (Figs 4A, 5A). Anterior buccal chamber surrounded by strongly developed sphincter muscle. Each mandible is also supported by a strong longitudinal and tangential musculature, altogether appearing as a muscular bulb. Pharynx muscularised, with developed glandular tissue throughout its entire length; with conspicuous anterior swelling surrounding the base of buccal cavity; pharynx widens posteriorly but not forming true posterior bulb. Cardia small, with cuticularized lumen. Secretory-excretory system present, renette body located at level with pharyngointestinal junction, secretory-excretory pore located at level with nerve ring. Tail straight, or curved either dorsally or ventrally, distinctly divided into conoid (in males and some females) or dome-shaped (in females) proximal and digitate distal sections. Caudal glands present, opening via a common spinneret, caudal gland cells/bodies incaudal.

\section{Male}

Reproductive system diorchic, with outstretched anterior testis and reflexed posterior testis, always on opposite sides of the intestine. Anterior testis on right $(n=4)$ side of intestine, posterior testis on left side $(n=4)$ of intestine. Spicules paired and symmetrical, elongate, seemingly consisting of two sections, subcylindrical proximal section and conoid/fusiform distal section, equal to 2.2-2.4 anal body diameters in length. Gubernaculum reduced to sublateral crura, subcylindrical to conoid in shape, with proximal swelling in some specimens, flanking distal part of spicules (Fig. 4I). Single midventral precloacal papilliform sensillum located $15 \mu \mathrm{m}$ from the cloacal opening (Fig. 4G). Further papilliform sensilla arranged in pairs subventrally and subdorsally anterior to cloaca and along tail.

\section{Female}

Reproductive system didelphic, amphidelphic, ovary branches reflexed antidromously. Anterior ovary on either right $(n=3)$ or left $(n=4)$ side of intestine, posterior ovary on either right $(n=5)$ or left $(n=2)$ side of intestine. Sperm present in the uterus. Vulva located at around midbody, a transverse slit. 


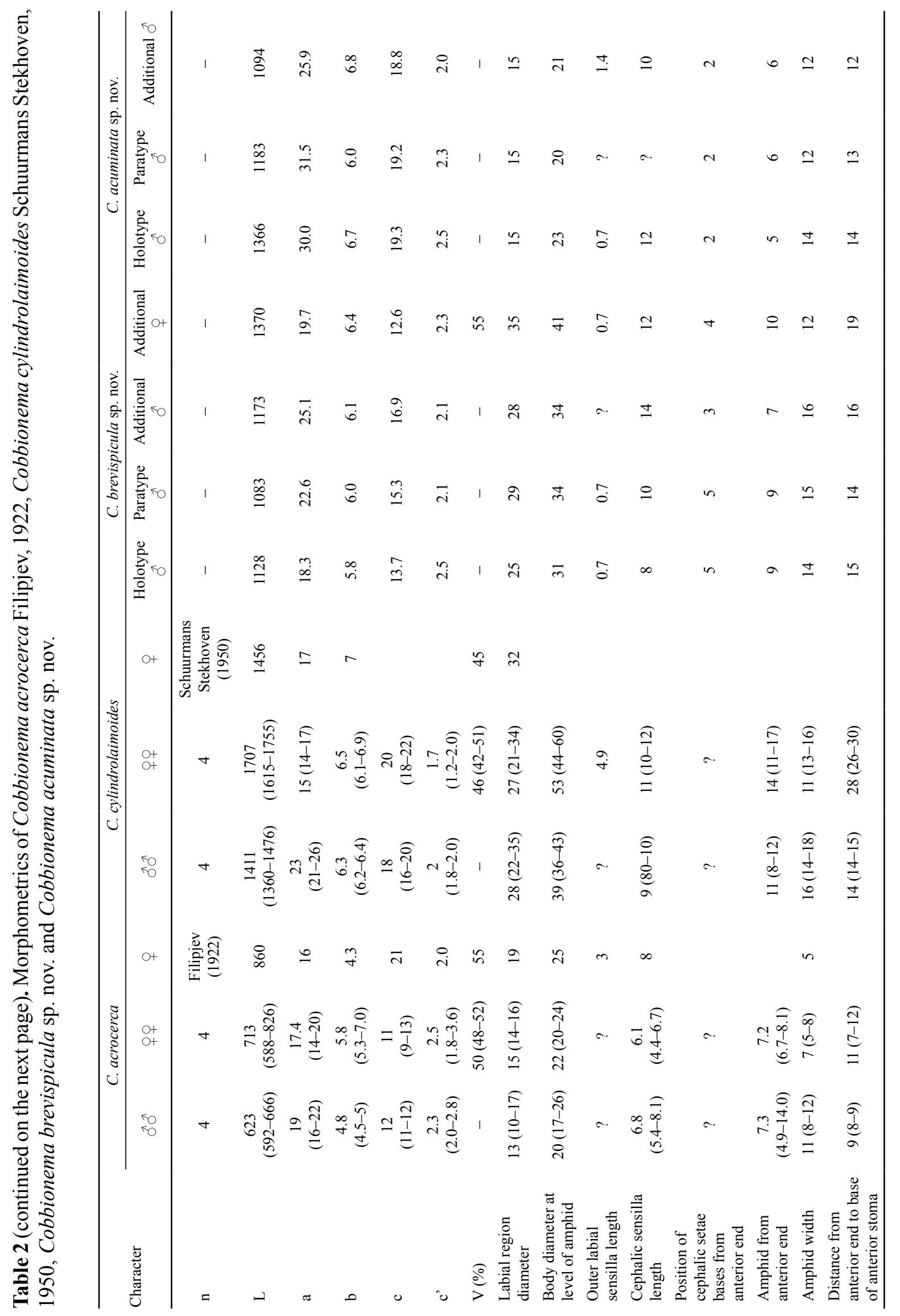




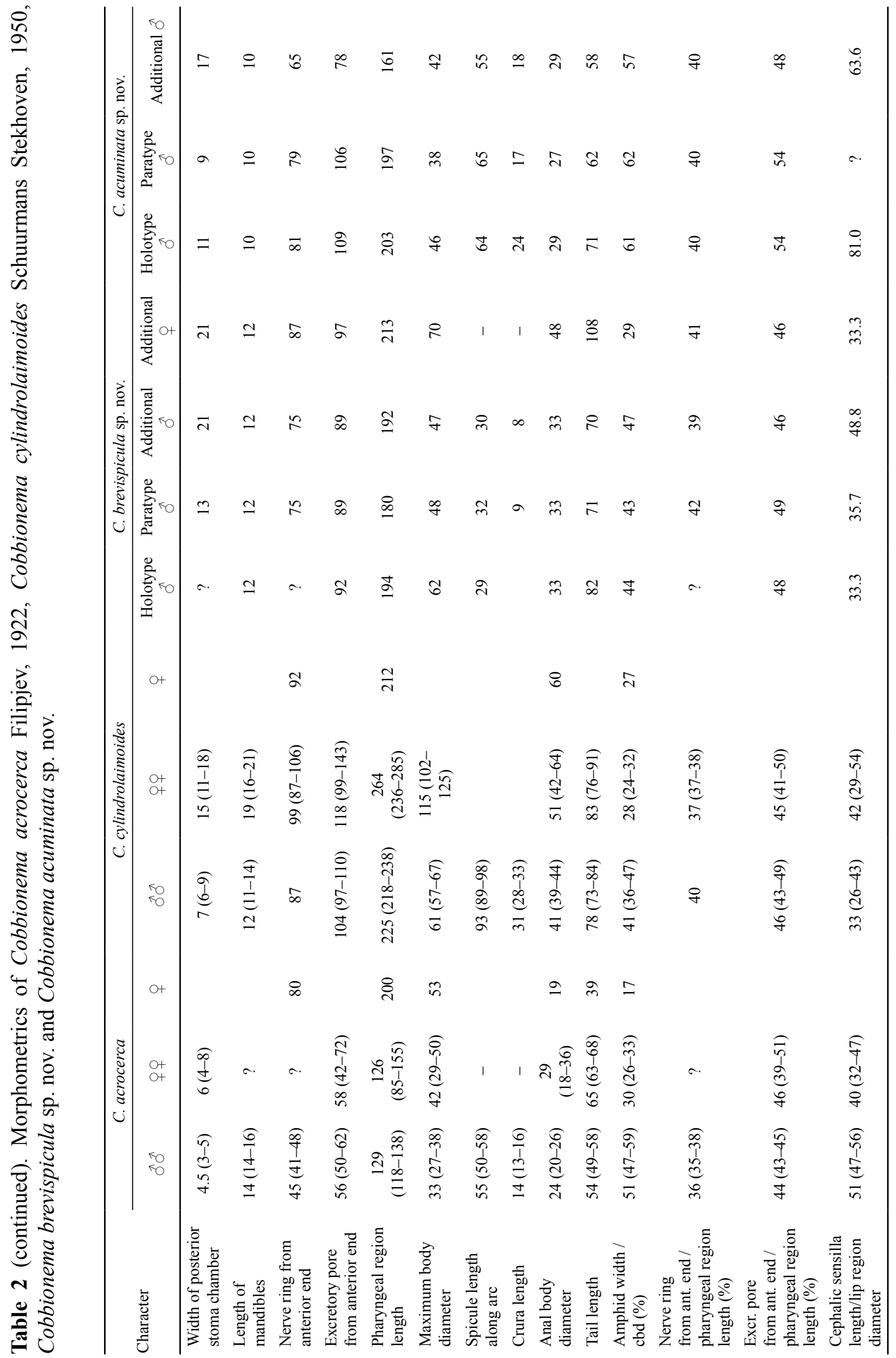



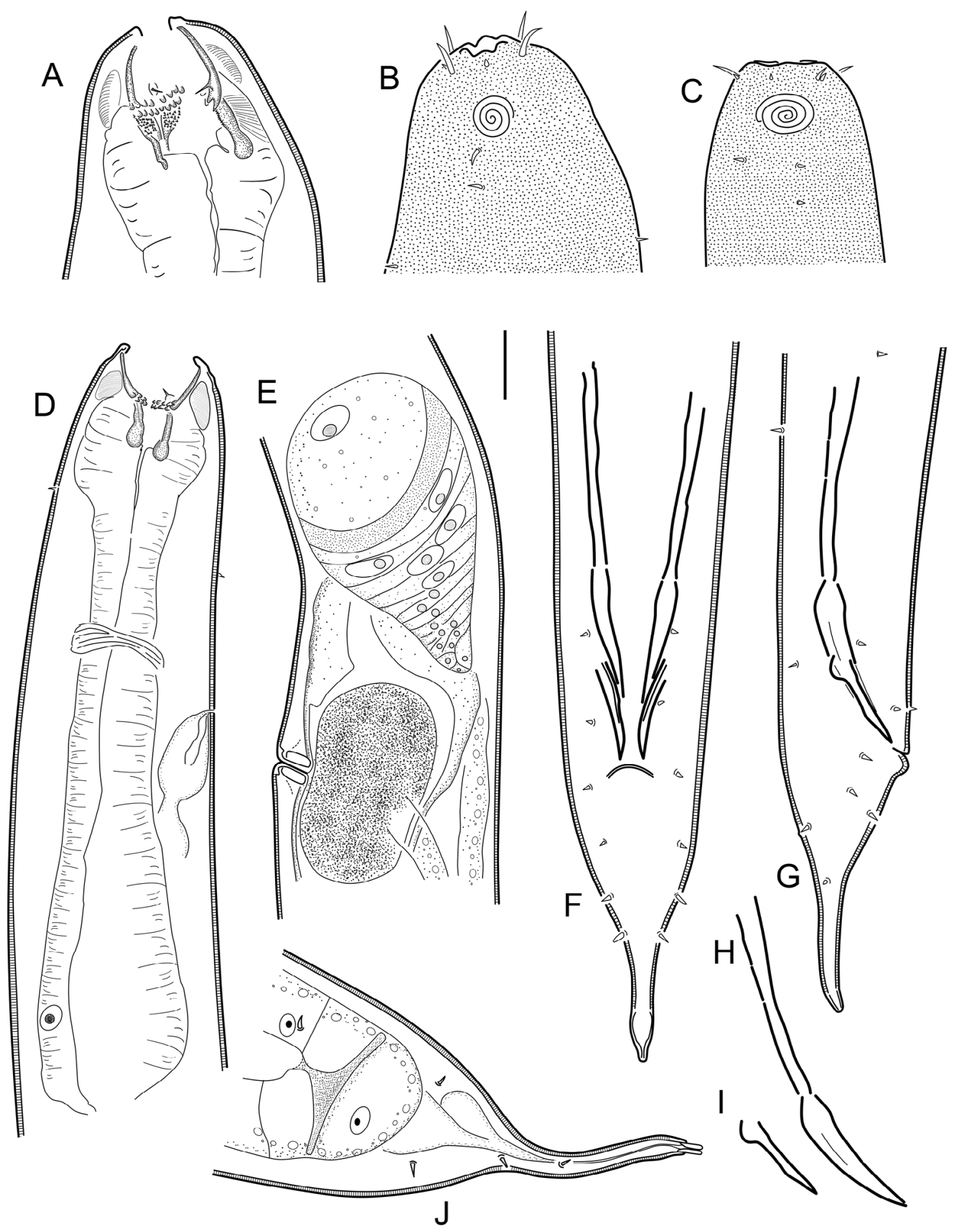

Fig. 4. Cobbionema cylindrolaimoides Schuurmans Stekhoven, 1950. A. Female head region (ventral side to the left) (SMNH-179211). B. Surface view of female head (ventral side to the left) (SMNH197211). C. Surface view of male head (ventral side to the right) (SMNH-179212). D. Anterior part of male (ventral side to the right) (SMNH-179212). E. Female mid body region showing anterior branch of the reproductive system and an egg (SMNH-179211). F. Dorsoventral view of spicules (SMNH179213). G. Lateral view of spicules (SMNH-179214). H. Spicule. I. Crura. J. Female tail (SMNH179211). Scale bar $=20 \mu \mathrm{m}$. 

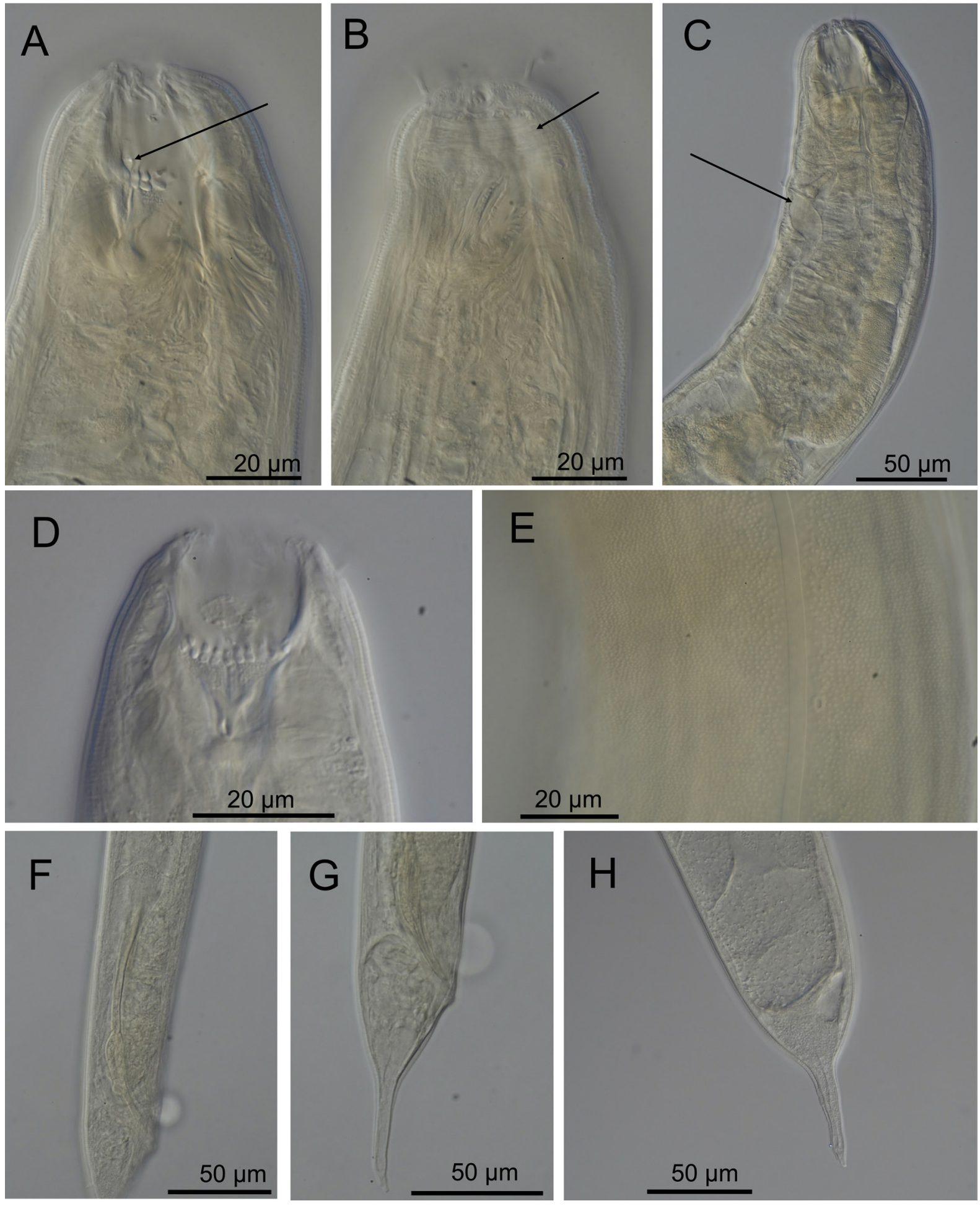

Fig. 5. Cobbionema cylindrolaimoides Schuurmans Stekhoven, 1950. Light micrographs. A. Female stoma showing stoma armament, arrow pointing to the right ventrosublateral tine (SMNH-179211). B. Anterior part of a female showing sphincter muscle surrounding the anterior stoma chamber (arrow) (SMNH-179212). C. Anterior part of a female with arrow showing the ampulla of the secretory-excretory system (SMNH-179211). D. Male stoma showing buccal armament (SMNH-179213). E. Cuticle showing lateral ala (SMNH-179211). F. Caudal region of a male showing spicule and crura (SMNH179214). G. Male tail (SMNH-179214). H. Female tail (SMNH-179212). 


\title{
Differential diagnosis
}

Swedish specimens of $C$. cylindrolaimoides resemble the only female specimen used by Schuurmans Stekhoven (1950) for the original description in body size and most body measurements (Table 2), presence of strongly cuticularized mandibles in the posterior stoma section and sigmoid-conoid shape of the tail. Gerlach (1964) synonymised it with C. acrocerca (and followed by Bezerra et al 2020) but in Gerlach \& Riemann (1974) they are treated as separate species. As discussed above, C. cylindrolaimoides differs from C. acrocerca in larger body $(1360-1755 \mu \mathrm{m}$ vs $588-860 \mu \mathrm{m}$ in C. acrocerca), longer spicules (89-98 $\mu \mathrm{m}$ vs 50-58 $\mu \mathrm{m}$ in C. acrocerca) and mandibles with strongly developed basal knobs (vs mandibles without discernible basal knobs) and shape of female tail.

Based on the updated morphological diagnosis, C. cylindrolaimoides most closely resembles the holotype male of $C$. trigamma in having relatively large body size $(1360-1476 \mu \mathrm{m}$ vs $1305 \mu \mathrm{m}$ in C. trigamma) and long spicules (89-98 $\mu \mathrm{m}$ vs $114 \mu \mathrm{m}$ in C. trigamma). The only clear morphological difference between $C$. cylindrolaimoides and $C$. trigamma is in the morphology of the cuticle (lateral alae present in $C$. cylindrolaimoides vs absent in C. trigamma). Paratypes of $C$. trigamma differ from C. cylindrolaimoides in much smaller body size $(1360-1755 \mu \mathrm{m}$ vs $566-600 \mu \mathrm{m}$ in both male and female C. trigamma).

Furthermore, C. cylindrolaimoides differs from C. capense, known from a single female, in body size (1456-1755 $\mu \mathrm{m}$ in females vs $688 \mu \mathrm{m}$ in C. capense), cuticle morphology (lateral alae present in C. cylindrolaimoides vs absent in C. capense) and different morphology of the stoma (see Table 3 ).

\section{Biology}

Gut content included undigested remains (spicules and gubernacula) or even partially digested entire bodies of a variety of nematode species, including Cyatholaimidae Filipjev, 1918 and Axonolaimidae Filipjev, 1918.

\author{
Cobbionema brevispicula sp. nov. \\ urn:1sid:zoobank.org:act:E6F3CD60-DCE1-4F96-BB28-410199A02705
}

Figs 6-7, Table 2

\section{Diagnosis}

Cobbionema brevispicula sp. nov. is characterised by $1.08-1.37 \mathrm{~mm}$ long body; lateral alae absent; body pores present; cephalic sensilla equal to $0.3-0.5$ labial region diameters in length; amphideal fovea sexually dimorphic, with 3.5-3.75 turns; two rows of pointed projections and a third row with three prominent sharply pointed tines in the stoma, rows of projections close to one another longitudinally; spicules elongate, nearly straight, with rounded manubrium, subcylindrical shaft and bifid tips, 29-32 $\mu \mathrm{m}$ long. Three or five midventral precloacal papilliform sensilla; tail curved ventrally and conoid in shape.

\section{Etymology}

The species name refers to relatively short spicule in the species, compared to other congeners.

\section{Material examined}

\section{Holotype}

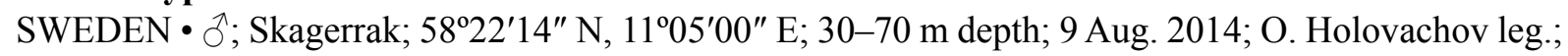
gravel, mud and algae; SMNH Type-9219.

\section{Paratypes}

SWEDEN • 2 ठ; same collection data as for holotype; SMNH Type-9220. 


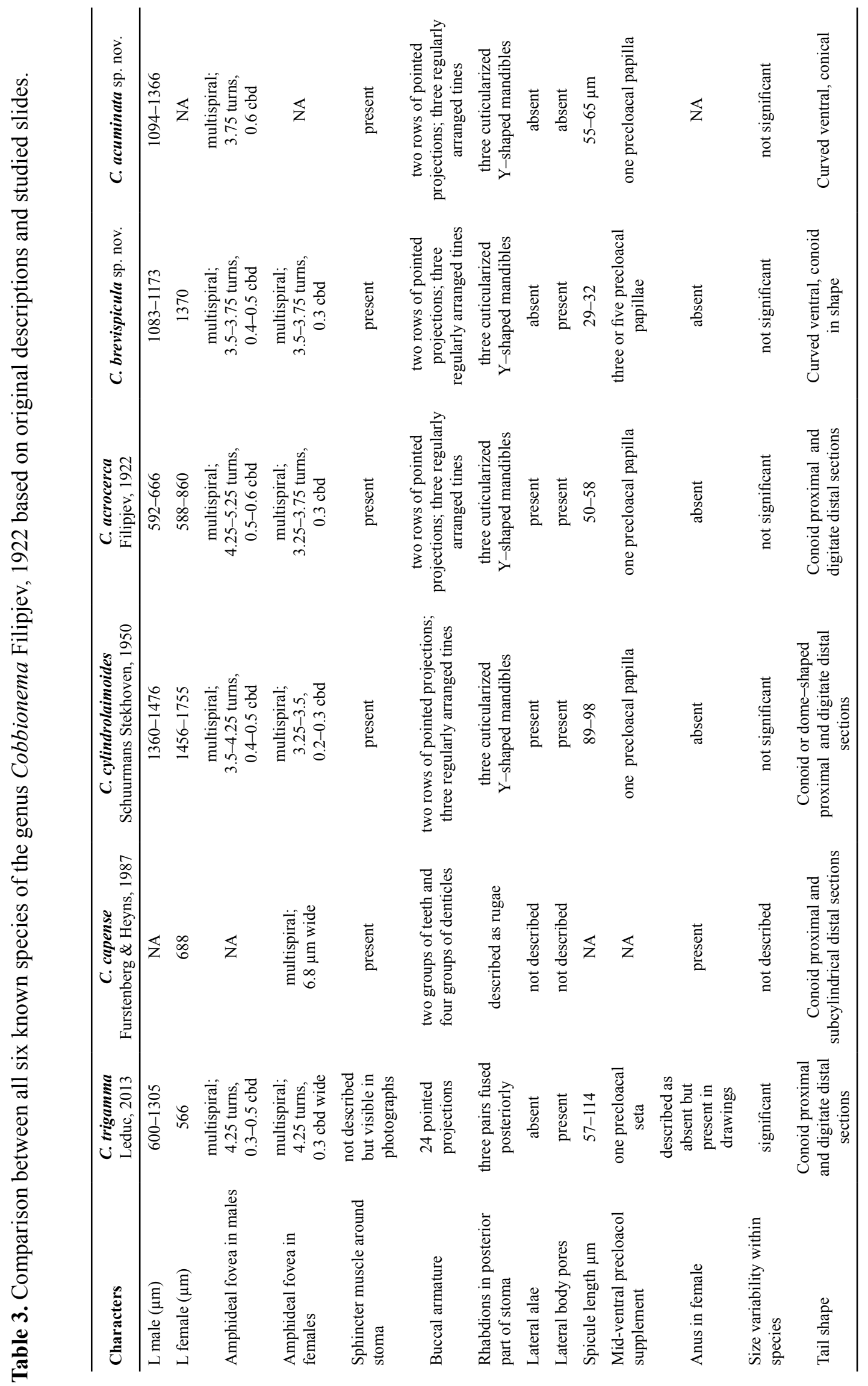


Additional non-type material

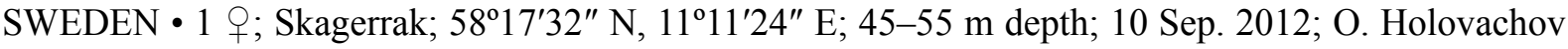
leg.; coarse sediment with algae; SMNH-182041.

\section{Description}

\section{Adult characters}

Body cylindrical, tapering slightly towards both extremities. Cuticle with transverse rows of dots, without lateral differentiation. Lateral alae in the shape of a smooth band of cuticle absent. Body pores present (fewer and less obvious in males), starting at level with anterior part of pharynx and extending to tail region, located along either side of the lateral alae, irregularly spaced. Somatic setae scattered along the body. Labial region bluntly-rounded, not set-off. Cephalic region of one male and a female demarcated by a broad and shallow constriction at level with amphid base (Fig. 6A-B); cephalic region of other two males subcylindrical (Fig. 6C-D); this is likely determined by the level of constriction of circum-stomatal sphincter. Six equal lips surrounding mouth opening. Inner labial sensilla indistinct. Outer labial sensilla small papilliform, located on the periphery of labial region. Cephalic sensilla setiform, equal to $0.3-0.5$ labial region diameters in length, located at the same level as outer labial sensilla. Amphideal fovea ventrosublateral, large, sexually dimorphic in size, multispiral with 3.5-3.75 turns, with circular outline, equal to about $0.4-0.5$ of the corresponding body diameter in male and 0.3 in female. Three to four pairs of cervical setae present, located posterior to amphid in ventrosublateral (1-2 pairs) and dorsosublateral ( 2 pairs) positions. Buccal cavity voluminous, divided into anterior and posterior chambers. Anterior chamber of buccal cavity barrel-shaped, with 12 cuticularized rhabdions, each with two pairs of large, pointed projections at posterior extremity. These projections are arranged in two horizontal rows, appearing from an en face view as two circles of denticles separating stoma into anterior and posterior chamber. Three (one middorsal and two ventrosublateral) prominent and hollow tines located a short distance in front of anterior circle of denticles. Posterior buccal chamber cone-shaped or cylindrical, widest at (posterior or anterior) extremity (depending on the state of stomatal musculature), with three strongly cuticularized Y-shaped mandibles; anterior branches of each mandible with a field of distinct denticles/knobs on its inner surface; posterior 'stem' of each mandible with strongly developed basal (submedian) knobs. Anterior buccal chamber surrounded by strongly developed sphincter muscle. Each mandible is also supported by a strong longitudinal and tangential musculature, forming a muscular anterior pharyngeal bulb. Pharynx muscularised, with developed glandular tissue throughout its entire length; the anterior pharyngeal bulb surrounds the base of buccal cavity; pharynx widens posteriorly but not forming true posterior bulb. Cardia small, with cuticularized lumen. Secretory-excretory system present, renette body located at level with pharyngo-intestinal junction, secretory-excretory pore located at level with nerve ring. Tail curved ventrally, conoid in shape. Caudal glands present, opening via a common spinneret, caudal gland cells/bodies incaudal in the majority of examined specimens, at level with posterior part of intestine in one male.

\section{Male}

Reproductive system diorchic, with outstretched anterior testis and reflexed posterior testis, always on opposite sides of the intestine. Anterior testis on either left (holotype) or right (paratype) side of intestine, posterior testis on either right (holotype) or left (paratype) side of intestine. Spicules paired and symmetrical, elongate, nearly straight, with rounded manubrium, subcylindrical shaft and bifid distal tips, equal to 0.9-1.0 anal body diameters in length (Figs 6H, 7F). Gubernaculum reduced to sublateral crura, conoid in shape, flanking distal part of spicules. Three or five midventral precloacal papilliform sensilla located in a row, starting 20-22 $\mu \mathrm{m}$ in front of cloacal opening. Further papilliform sensilla arranged as follows: one subventral pair located half-way between posteriormost midventral papilliform sensillum and cloacal opening; several subventral and several subdorsal pairs along the tail in a variable manner (Fig. 6F-G). 


\section{Female}

Reproductive system didelphic, amphidelphic, ovary branches reflexed antidromously. Anterior ovary on right side of intestine, posterior ovary on left side of intestine. Other details of female reproductive system morphology cannot be observed due to suboptimal preservation of the specimen. Vulva located
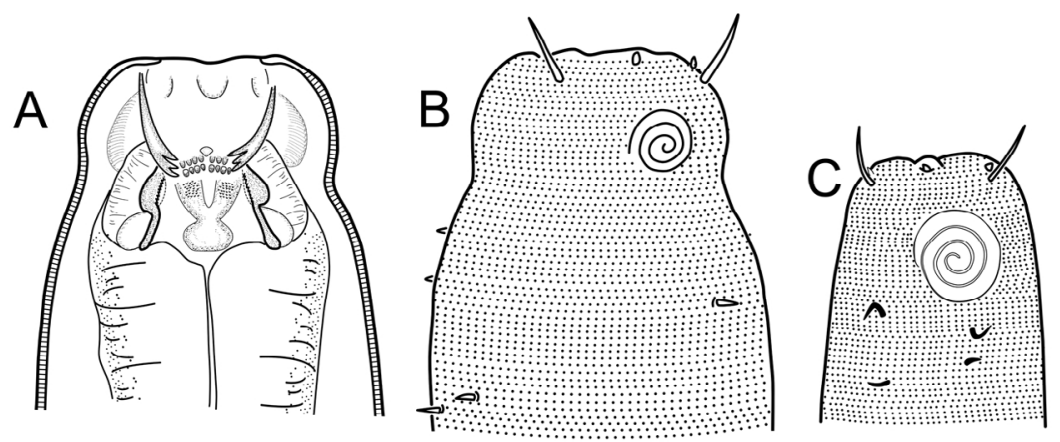

$\mathrm{D}$
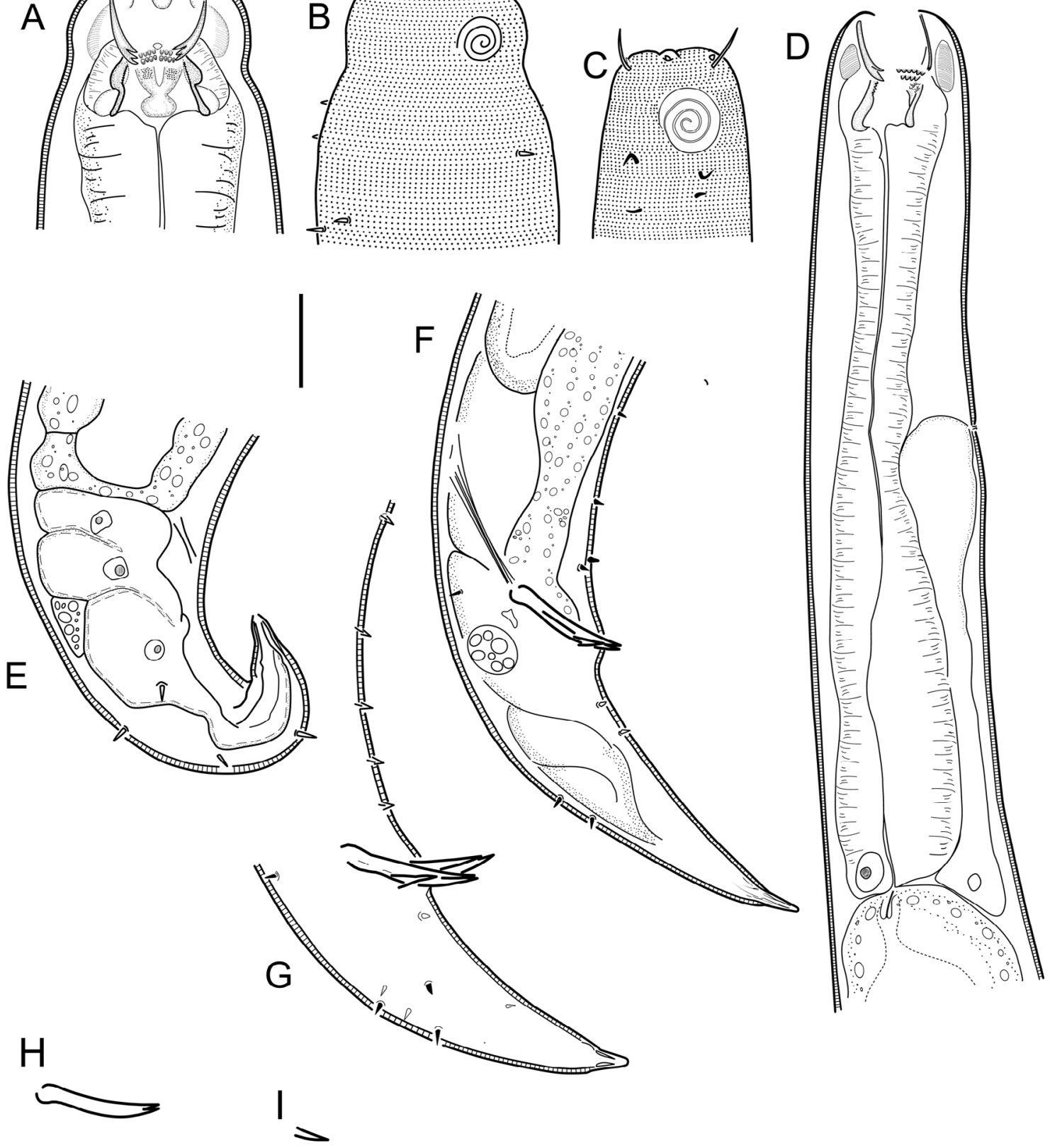

Fig. 6. Cobbionema brevispicula sp. nov. A. Female head region (ventral side to the right) (SMNH182041). B. Surface view of female head (ventral side to the right) (SMNH-182041). C. Surface view of the male holotype head (ventral side to the right) (SMNH Type-9219). D. Anterior part of male holotype (ventral side to the right) (SMNH Type-9219). E. Female caudal region (SMNH-182041). F-G. Male holotype caudal region (SMNH Type-9219). H. Spicule. I. Crura. Scale bar $=20 \mu \mathrm{m}$. 

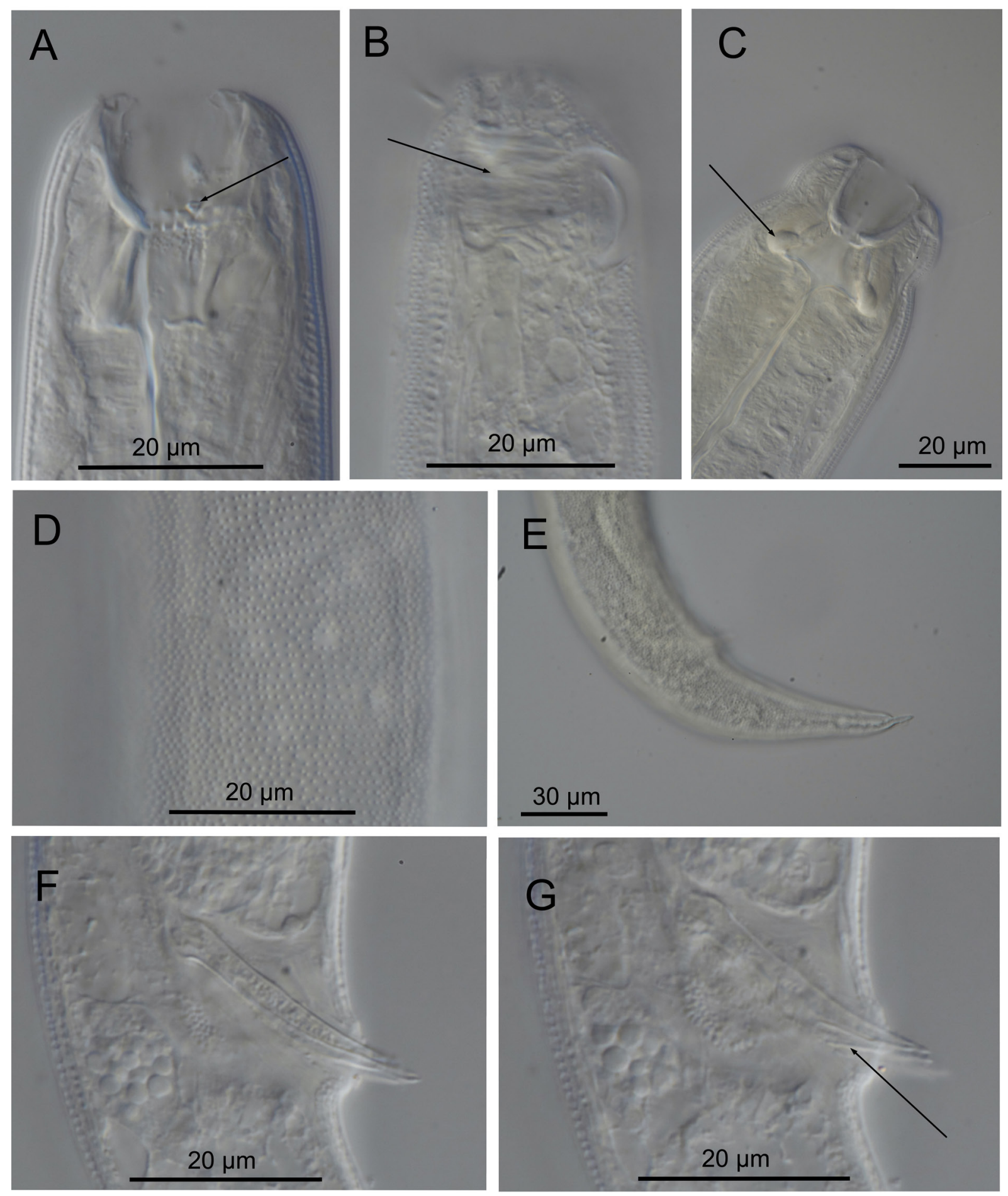

Fig. 7. Cobbionema brevispicula sp. nov. Light micrographs. A. Stoma of male holotype showing stoma armament, arrow pointing to the left ventrosublateral tine (SMNH Type-9219). B. Anterior part of male holotype showing sphincter muscle surrounding the anterior end of posterior stoma chamber (arrow) (SMNH Type-9219). C. Anterior part of a female; arrow pointing to a mandible with heavily cuticularized basal knob (SMNH-182041). D. Cuticle showing no lateral ala (SMNH Type-9219). E. Male tail (SMNH Type-9219). F. Caudal region of male holotype showing spicule (SMNH Type9219). G. Caudal region of male holotype showing crura (arrow) (SMNH Type-9219). 
just posterior to midbody. Intra-uterine egg not seen. Rectum reduced, a string of undifferentiated tissue stretching from posterior blunt end of intestine towards ventral body side is visible.

\title{
Differential diagnosis
}

Both males and females of $C$. brevispicula sp. nov. can be distinguished from all previously described species of Cobbionema by their conical tail (vs conoid proximal portion and digitate distal section). Males of $C$. brevispicula sp. nov. are also different from all other previously described species in the unique shape and size of their spicules (nearly straight, with bifid tips and measuring $0.9-1.0$ anal body diameters long vs two-sectioned spicules consisting of subcylindrical proximal part and a conoid/ fusiform distal section and measuring 1.9-2.8 anal body diameters long).

\section{Biology}

Gut content included undigested remains (spicules and gubernacula) of a variety of nematode species, including a possible Cyatholaimidae.

\author{
Cobbionema acuminata sp. nov. \\ urn:1sid:zoobank.org:act:AF9C8B50-B488-4425-A883-8A1ACAB423E7
}

Figs $8-9$, Table 2

\section{Diagnosis}

Cobbionema acuminata sp. nov. is characterised by $1.09-1.37 \mathrm{~mm}$ long body; lateral alae and body pores absent; cephalic sensilla equal to 0.6-0.8 labial region diameters in length; amphideal fovea large, with 3.75 turns; two rows of pointed projections and three prominent sharply pointed tines in the stoma, rows of projections wider apart longitudinally; spicules consisting of two sections, 55-65 $\mu \mathrm{m}$ long; single midventral precloacal papilliform sensillum; tail curved ventrally, conical in shape.

\section{Etymology}

The species name refers to the presence of acute, sharply pointed tines in the stoma.

\section{Material examined}

\section{Holotype}

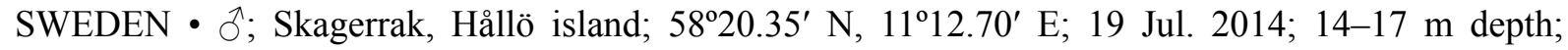
O. Holovachov leg.; sand and shells; SMNH Type-9221.

\section{Paratype}

SWEDEN • 1 đ̊; same collection data as for holotype; SMNH Type-9222.

\section{Additional non-type material}

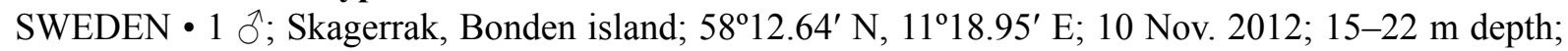
O. Holovachov leg.; sand and shells; SMNH-182043.

\section{Description}

\section{Adult characters}

Body cylindrical, tapering slightly towards both extremities. Cuticle with transverse rows of dots, without lateral differentiation. Lateral alae absent. Body pores absent. Somatic setae scattered along the body. Labial region bluntly-rounded, not set-off, but cephalic region demarcated by a broad and shallow constriction at level with amphidial fovea. Six equal lips surrounding mouth opening. Inner labial sensilla indistinct. Outer labial sensilla small papilliform, located on the periphery of labial region. 
Cephalic sensilla setiform, equal to 0.6-0.8 labial region diameters in length, located at the same level as outer labial sensilla. Amphideal fovea ventrosublateral, large, multispiral with 3.75 turns, with circular outline, equal to about 0.6 of the corresponding body diameter. Four pairs of cervical setae present, located just posterior to amphid in ventrosublateral (at the base of each amphid) and dorsosublateral positions (Fig. 8B). Buccal cavity voluminous, divided into anterior and posterior chambers. Anterior chamber of buccal cavity barrel-shaped, with 12 cuticularized rhabdions, each with two pairs of large, pointed projections at posterior extremity. These projections are arranged in two horizontal rows, appearing from an en face view as two circles of denticles separating stoma into anterior and posterior chamber. Three (one middorsal and two ventrosublateral) prominent and sharply pointed tines (with hollow conoid base) located a short distance in front of anterior circle of denticles. Posterior buccal chamber cone-shaped, widest at (posterior or anterior) extremity (depending on the state of stomatal musculature), with strongly cuticularized Y-shaped mandibles; anterior branches of each mandible with a field of minute denticles/knobs on its inner surface; posterior 'stem' of each mandible with strongly developed basal (submedian) knobs. Anterior buccal chamber surrounded by strongly developed sphincter muscle. Each mandible is also supported by a strong longitudinal and tangential musculature, altogether appearing as a muscular bulb. Pharynx weakly muscularised, with strongly developed glandular tissue throughout its entire length; with conspicuous anterior swelling surrounding the base of buccal cavity; pharynx widens posteriorly but not forming true posterior bulb. Cardia small, with cuticularized lumen. Secretory-excretory system present, renette body located at level with pharyngointestinal junction, secretory-excretory pore located short distance posterior to nerve ring. Tail curved ventrally, conical in shape. Caudal glands present, opening via a common spinneret, caudal gland cells/ bodies at level with posterior part of intestine, anterior to cloaca.

\section{Male}

Reproductive system diorchic, with outstretched anterior testis and reflexed posterior testis. Anterior testis on right side of intestine, posterior testis on left side of intestine. Spicules paired and symmetrical, elongate, seemingly consisting of two sections separated by a constriction, subcylindrical/fusiform proximal section and conoid distal section, equal to 1.9-2.4 anal body diameters in length. Gubernaculum reduced only to sublateral crura, arcuate conoid in shape, flanking distal part of spicules. Single midventral precloacal papilliform sensillum located $17 \mu \mathrm{m}$ in front of cloacal opening (Fig. 8D). Further six papilliform sensilla arranged as follows: one subventral pair located half-way between midventral papilliform sensillum and cloacal opening; one subventral pair short distance posterior to cloalcal opening and one ventro-sublateral pair at anterior third of tail length. One pair of dorsosublateral setae located along middle third of tail.

\section{Female}

Not found.

\section{Differential diagnosis}

Cobbionema acuminata sp. nov., known from three males, differs from all previously described species in arrangement of the stoma armaments (rows of pointed projections and tines widely spaced longitudinally vs rows of projections and tines closer longitudinally in all other species, the three sharply pointed tines more erect and prominent vs pointed posteriorly and shorter in other species). Cobbionema acuminata sp. nov. is also unique in its lack of body pores (present in all other species except for $C$. capense where no mention was made of the presence or absence of body pores in the description). Cobbionema acuminata sp. nov. differs from males of $C$. acrocerca and C. cylindrolaimoides in its tail shape (conical in C. acuminata sp. nov. vs conoid proximal and digitate distal sections in C. acrocerca and $C$. cylindrolaimoides) and lacking lateral alae (present in C. acrocerca and C. cylindrolaimoides). Cobbionema acuminata sp. nov. also differs from $C$. acrocerca in most body measurements (see Table 2). Cobbionema acuminata sp. nov. differs from holotype and paratype males of C. trigamma 
A
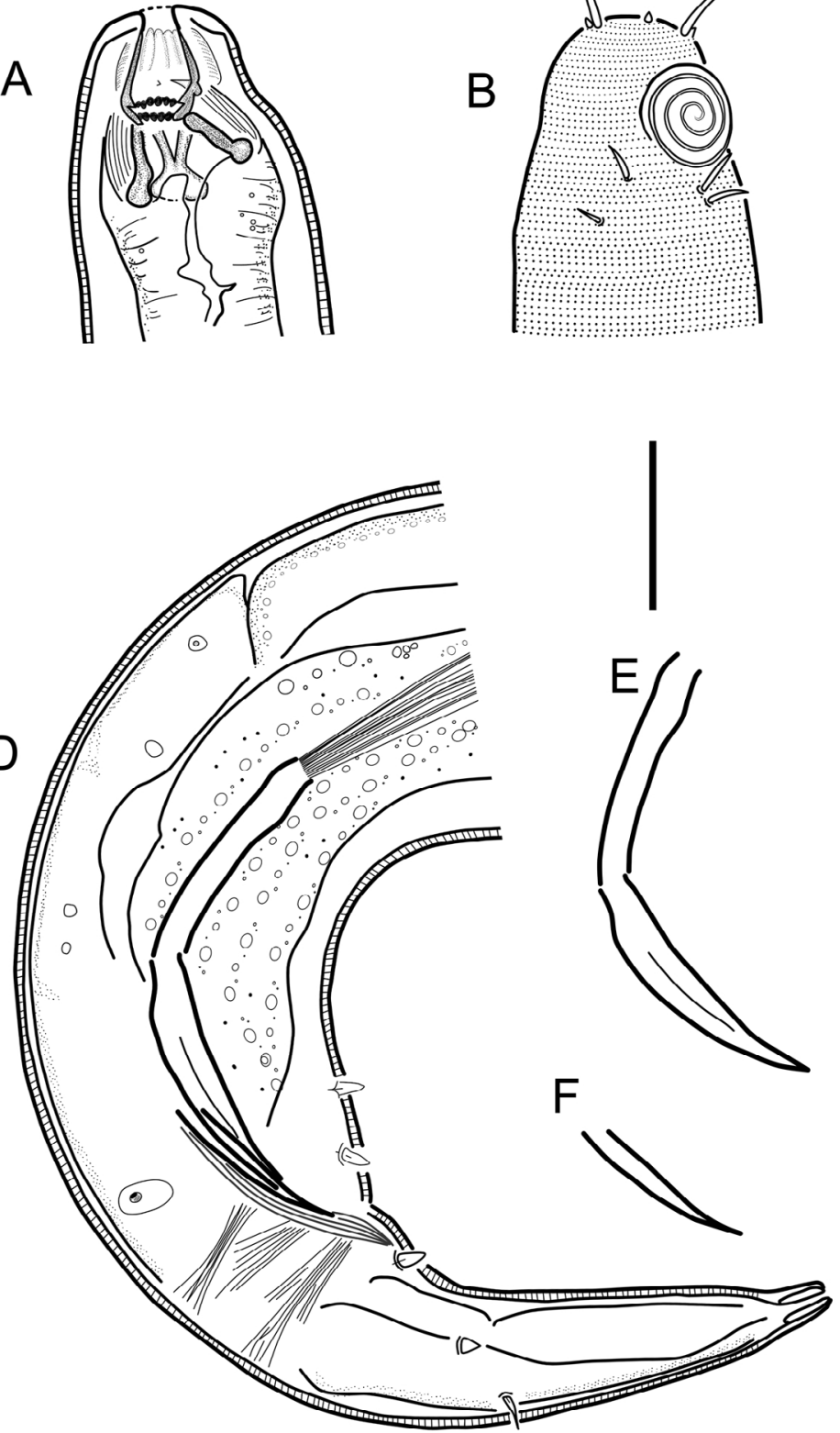
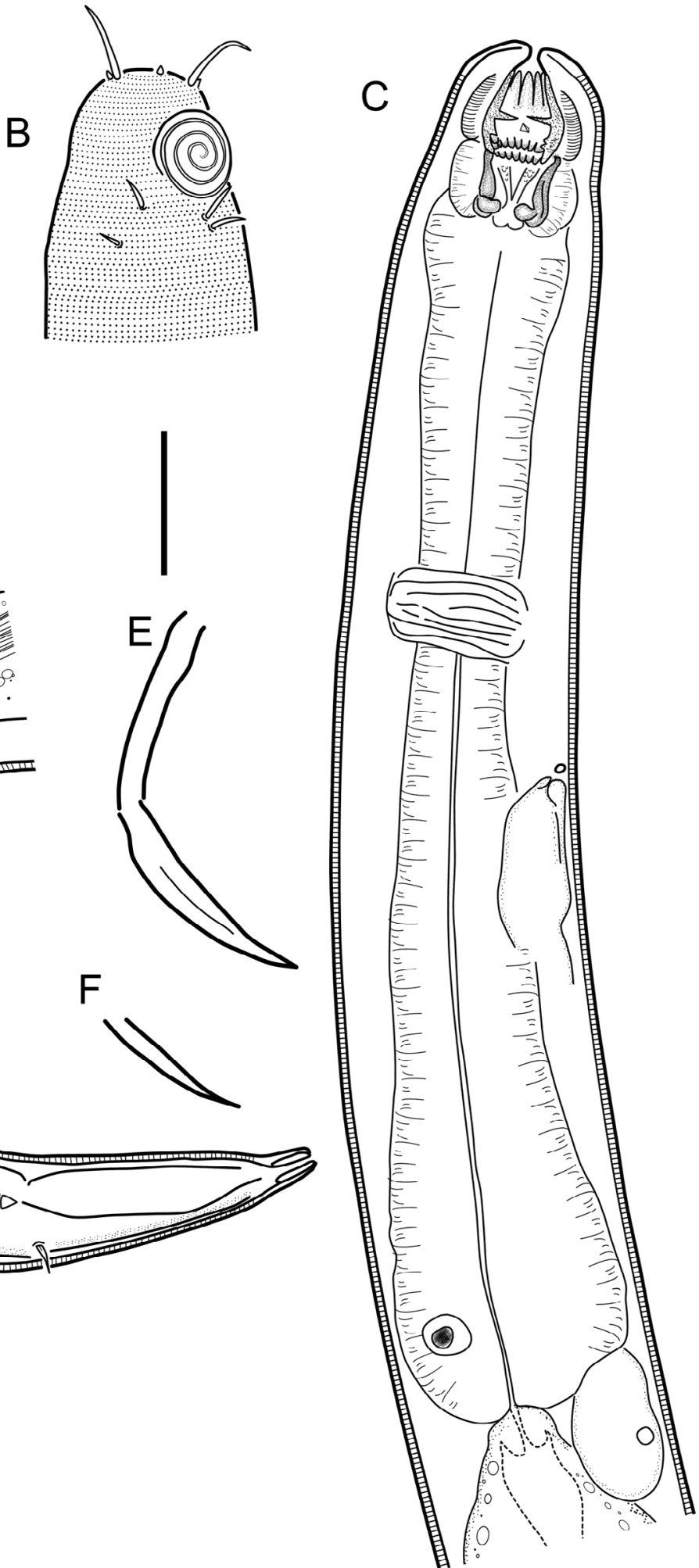

Fig. 8. Cobbionema acuminata sp. nov. A. Male paratype head region (ventral side to the right) (SMNH Type-9222). B. Surface view of male holotype head (ventral side to the right) (SMNH Type-9221). C. Anterior part of male holotype (ventral side to the right) (SMNH Type-9221). D. Caudal region of male holotype (SMNH Type-9221). E. Spicule. F. Crura. Scale bar $=20 \mu \mathrm{m}$. 
in its body diameter (25.9-31.5 vs 16 and 17 in holotype and paratype of $C$. trigamma), number of pointed projections in the stoma (48 vs 24 in C. trigamma) and tail shape (conical vs conoid proximal and digitate distal sections in C. trigamma). Because C. capense is known only from a single female specimen, its comparison with $C$. acuminata sp. nov., for which no female specimens were found, cannot be based on a character with known sexual dimorphisms such as body size. The two can be distinguished based on their tail shape (conical vs conoid proximal and subcylindrical distal sections in C. capense). Cobbionema acuminata sp. nov. resembles males of $C$. brevispicula sp. nov. in body length (1094-1366 $\mu \mathrm{m}$ vs 1083-1173 $\mu \mathrm{m})$. The two, however, can be distinguished by their spicule shape and
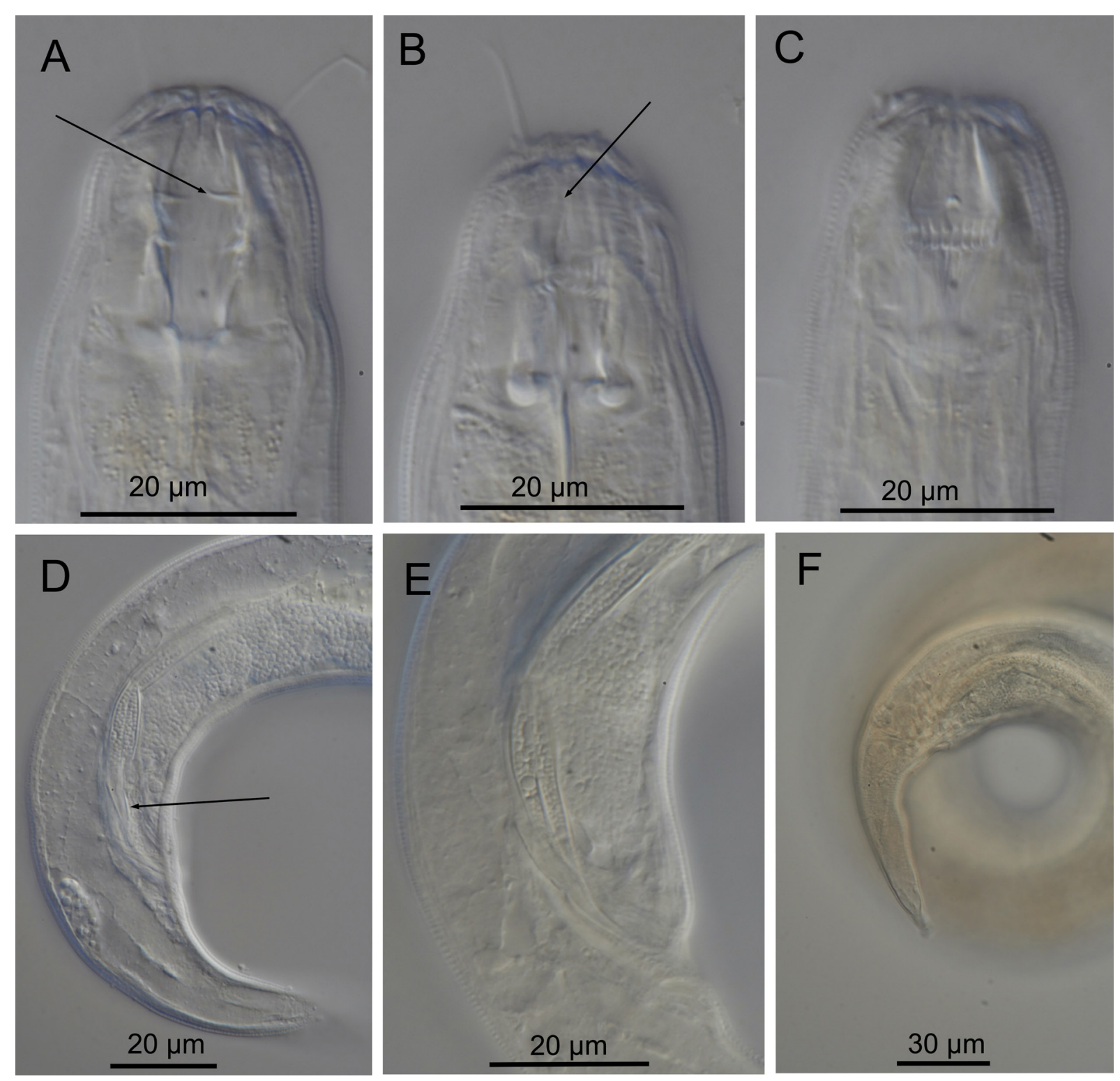

Fig. 9. Cobbionema acuminata sp. nov. Light micrographs. A. Stoma of male holotype (SMNH Type9221) showing stoma armament, arrow pointing to the right ventrosublateral tine. B. Anterior part of a male showing sphincter muscle surrounding the anterior stoma chamber (arrow). C. Stoma of male holotype (SMNH Type-9221) showing the arrangement of the pointed projections and the left ventrosublateral tine. D-E. Caudal region of male paratype (SMNH Type-9222) showing the crura (arrow) and spicule. F. Male tail, holotype (SMNH Type-9221). 
length (two-sectioned spicules consisting of subcylindrical proximal part and a conoid/fusiform distal section and measuring 1.9-2.4 anal body diameters long vs nearly straight, with bifid tips and measuring $0.9-1.0$ anal body diameters long).

\section{Molecular phylogeny}

Both the 18S and 28S rRNA genes datasets were analysed using Maximum Likelihood (RAxML) and Bayesian inference methods (mcmcphase in PHASE 3). Analysis of the 18S rRNA dataset produced similar, but not identical tree topologies for the Maximum Likelihood and Bayesian inference methods (see Figs 10-11). The main topological differences between the two approaches concerned the relationship between Choniolaimus papillatus and the ((Halichoanolaimus + Demonema Cobb, 1894) + Cobbionema) clade and the relationship between Choanolaimus psammophilus de Man, 1880 and Synonchium sp. Similarly, the 28S rRNA dataset produced tree topologies that were broadly comparable for the two inference methods (see Figs 12-13). The main difference between the tree topologies involves the position of Pseudocheironchus ingluviosus Leduc, 2013, the position of Cobbionema within the (Bendiella + Cobbionema + Demonema + Halichoanolaimus) clade and the relationships

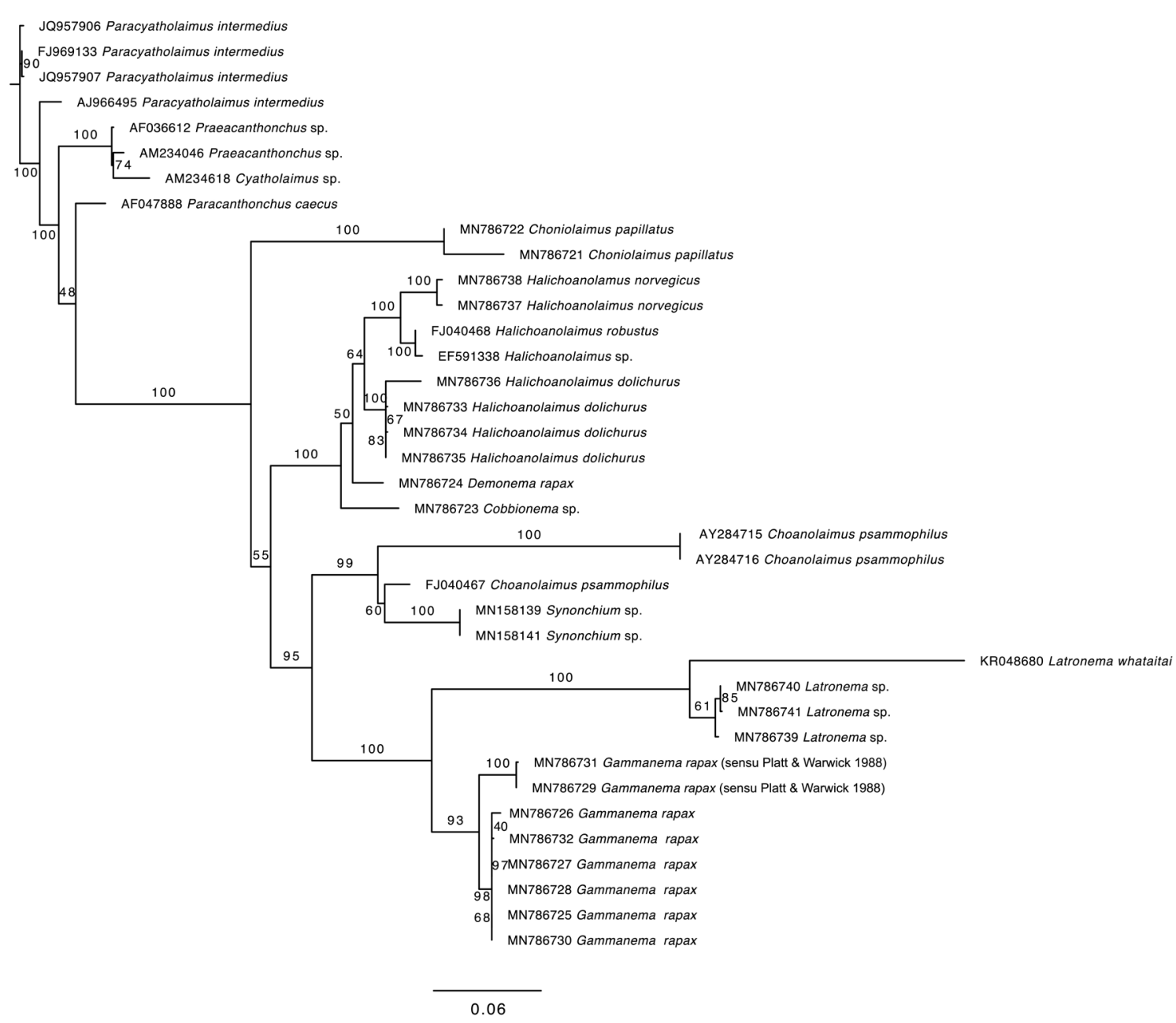

Fig. 10. Maximum Likelihood phylogenetic tree of Selachinematidae Cobb, 1915 inferred from 18S rRNA data, using alignments based on secondary structure models using GTR GAMMA for unpaired sites and RNA7A for paired sites. 
within the Latronema Wieser, 1954 clade. All four trees indicate a close relationship between Latronema and Gammanema Cobb, 1920 through strong branch support (bootstrap support: 94-100 and posterior probability: 1). Cobbionema and Halichoanolaimus were nested within the same clade as was expected based on their morphological similarities. Demonema was also embedded within the same clade.

\section{Discussion}

This study presents the first record of the genus Cobbionema in Sweden. Other new records for the family Selachinematidae include Choniolaimus crassus Vitiello, 1971, C. panicus Gerlach, 1956, Halichoanolaimus norvegicus, Gammanema rapax and Synonchiella riemanni Warwick, 1970 (https://dyntaxa.se/Taxon/Info/2000413). Including the two new species of Cobbionema to the list of new records increases it to nine, making an overall total of 16 species for the Swedish fauna. The entire family list now comprises four species of Halichoanolaimus, four species of Choniolaimus, two species of Synonchiella Cobb, 1933, one species of Gammanema, one species Latronema and four species of Cobbionema (Table 4).

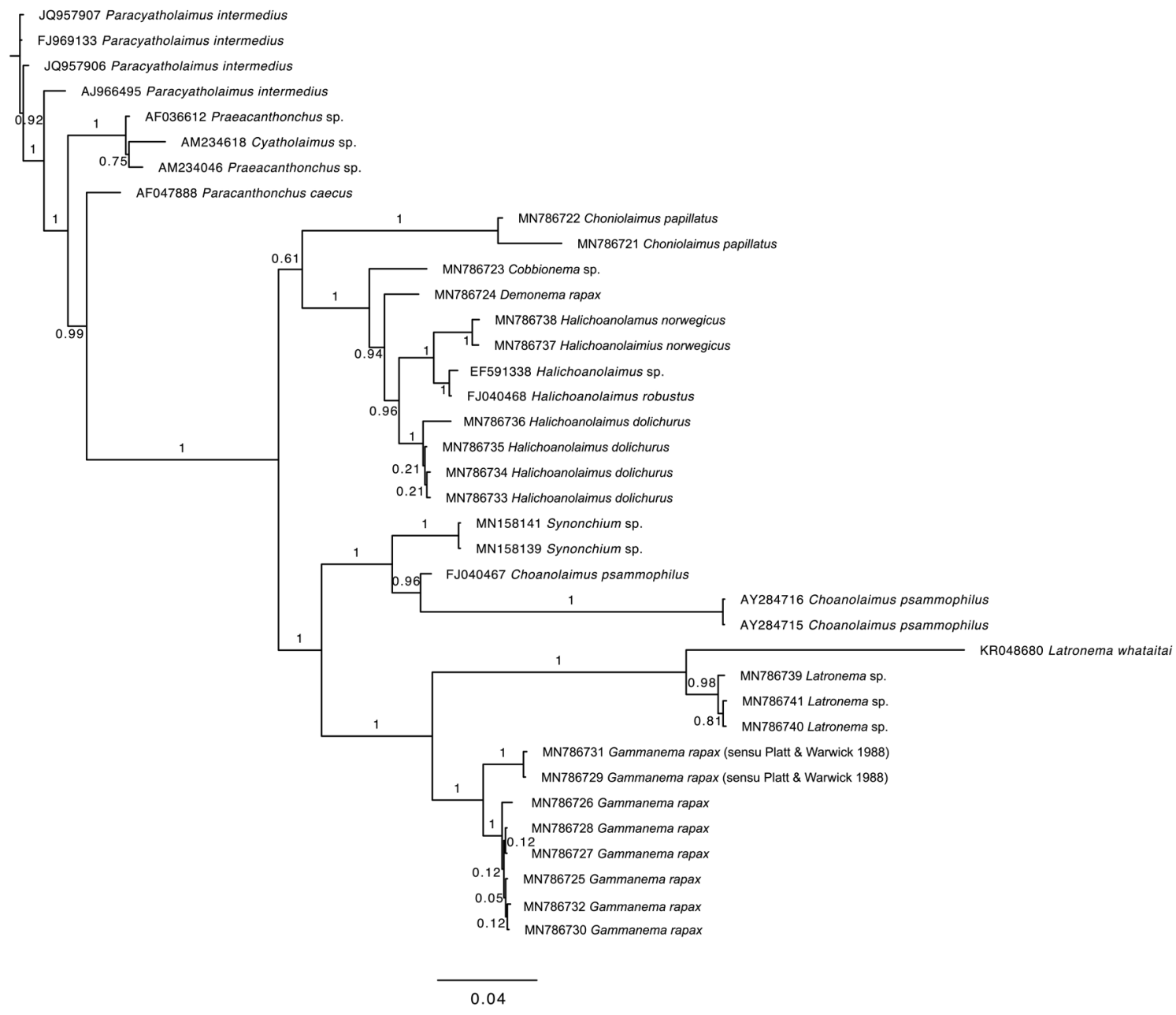

Fig. 11. Bayesian phylogenetic tree of Selachinematidae Cobb, 1915 inferred from 18S rRNA data, using alignments based on secondary structure models using REV GAMMA for unpaired sites and RNA16A for paired sites. 
Morphologically, Cobbionema is unique among the other genera of the family in the spicule shape in males, the sphincter muscle around the anterior stoma chamber and in having anterior not posterior pharyngeal bulb. The first ever mention of the sphincter muscle around the anterior part of the stoma was made in the original description of the type species, C. acrocerca, by Filipjev (1922). In the description of $C$. cylindrolaimoides, although no reference was made on the presence of such sphincter muscle, the similarities in the stoma armament of Cobbionema and that of Halichoanolaimus was mentioned. Furstenberg \& Heyns (1987) provided a detailed description of the stoma armament of $C$. capense, the third member of the genus, and which as the aforementioned two, was described without males. The description of $C$. trigamma, which included males for the first time, also described in more detail the structure of the stoma. Based on the description of C. trigamma and all four species examined in this study, the gamma-shaped rhabdions in the posterior chamber of the buccal cavity used to distinguish C. trigamma from the other species of Cobbionema is most likely a shared character for the genus. Furthermore, the total number of pointed projections in the stoma could be more than previously reported (at least 48 in all species examined in this study). Aside from the substantial size difference between C. acrocerca and C. cylindrolaimoides, and perhaps the way that this manifests into difference in mandibular cuticularization and spicule size, they share almost all of the useful species diagnosis features

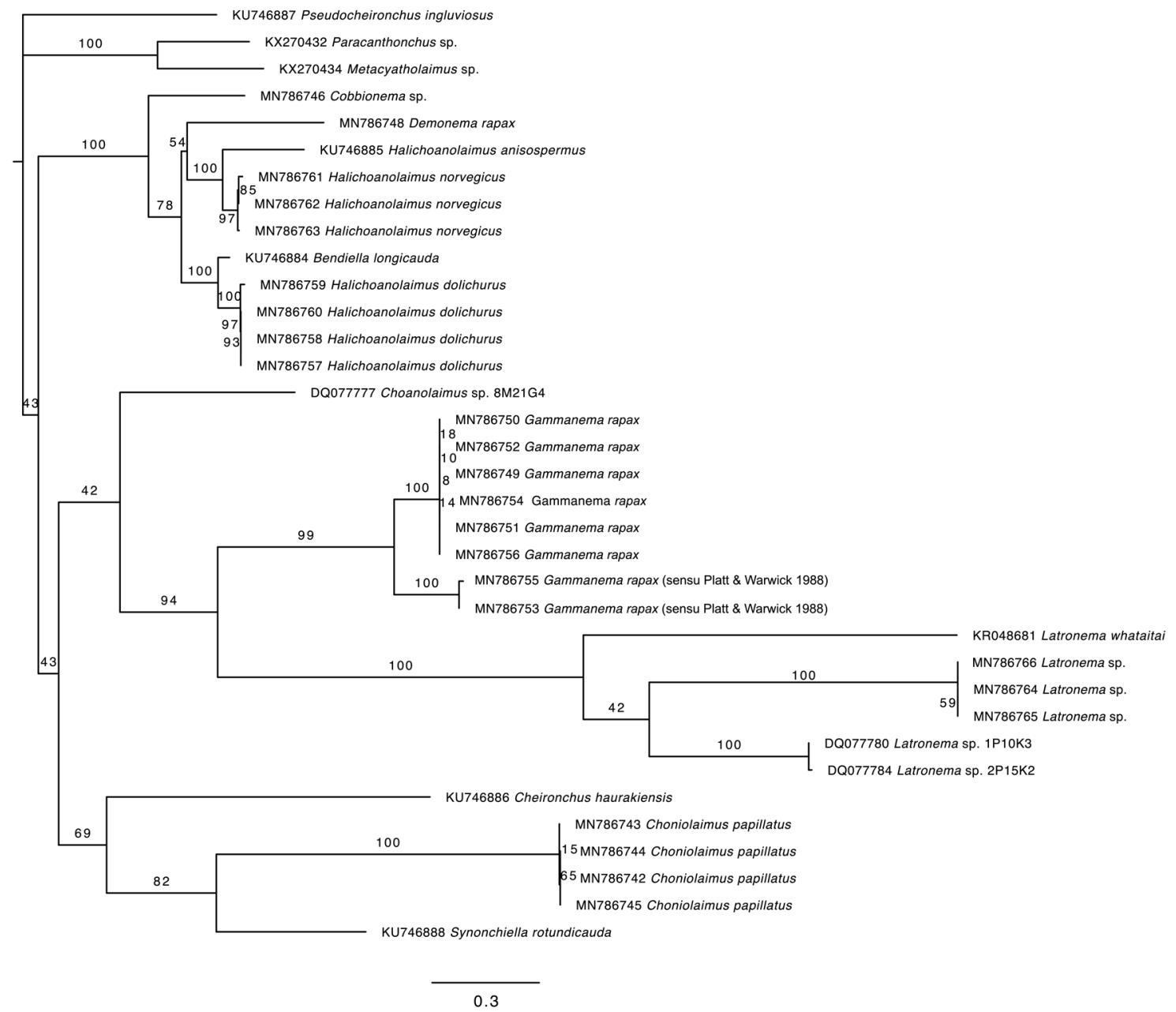

Fig. 12. Maximum Likelihood phylogenetic tree of Selachinematidae Cobb, 1915 inferred from 28S rRNA data, using alignments based on secondary structure models using GTR GAMMA for unpaired sites and RNA7A for paired sites. 
of the genus such as stoma morphology, lateral differentiation, spicule shape and tail shape. Considering how small the paratype male of $C$. trigamma is compared to the holotype, it is possible that, as Gerlach (1964) implied, C. cylindrolaimoides and C. acrocerca are conspecific and that the former only represent a population of the latter with a larger body size. On the other hand, the discovery of numerous sibling/ cryptic species, which are morphologically similar but genetically distinct (Derycke et al. 2005, 2010) suggests that $C$. cylindrolaimoides and $C$. acrocerca may be another such example. The use of molecular data may be able to provide a definitive answer as to the status of $C$. cylindrolaimoides in relation to C. acrocerca and perhaps that of the paratype of C. trigamma in relation to its holotype. With such data unavailable at the moment, we would like to maintain the valid species status of $C$. cylindrolaimoides.

Although the set of taxa used for the phylogenetic inference was not exactly the same for the two genes, their overall topologies are similar. Given the suboptimal representation of the family in this analysis, inferences made here should be seen as based on current set of taxa included only. Nevertheless, the placement of Demonema within the same branch as Halichoanolaimus and Cobbionema was unexpected. This is because, while a number of shared morphological characteristics exist that suggests a possible close phylogenetic relationship between Cobbionema and Halichoanolaimus, the two do not possess

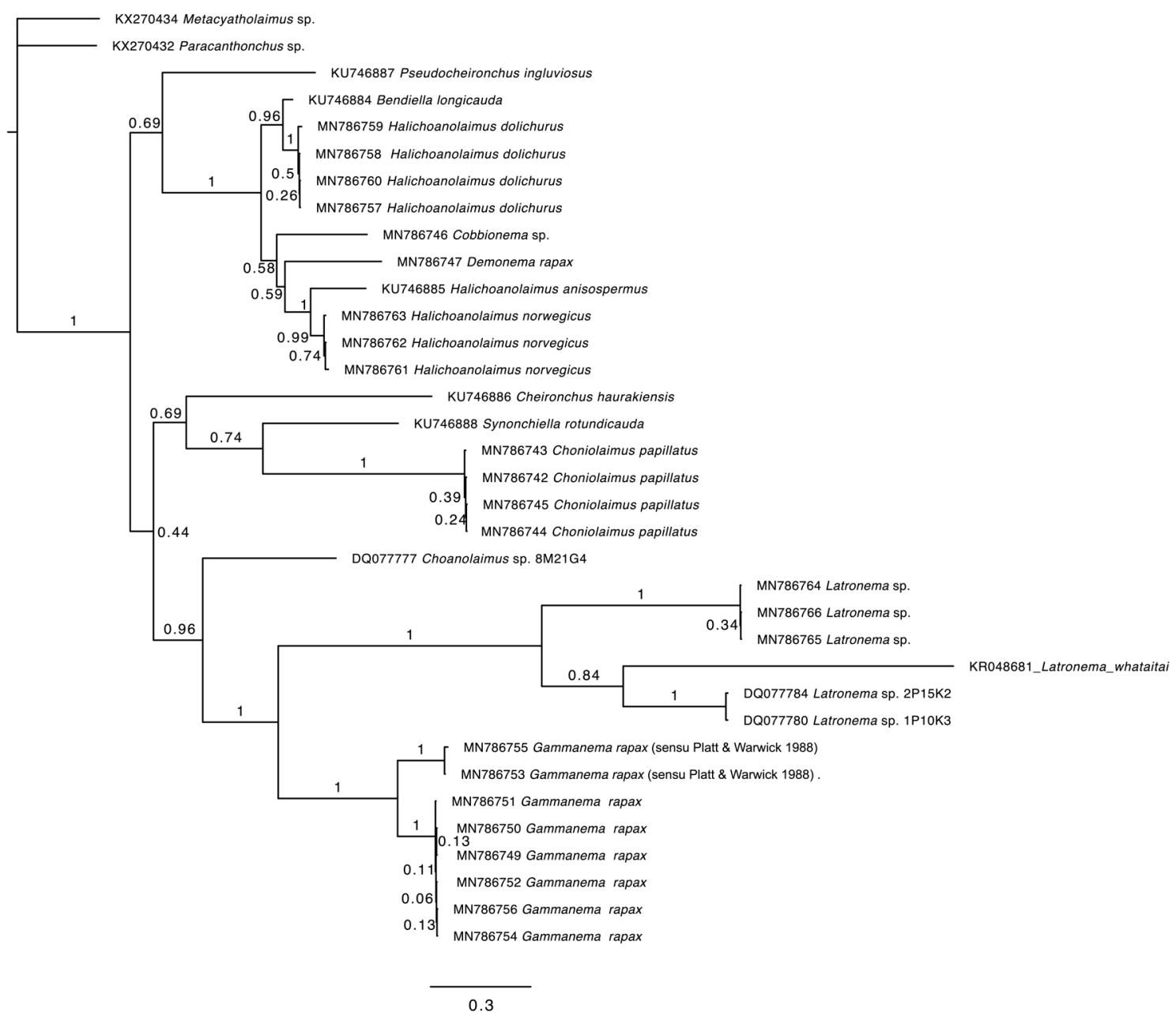

Fig. 13. Bayesian phylogenetic tree of Selachinematidae Cobb, 1915 inferred from 28S rRNA data, using alignments based on secondary structure models using REV GAMMA for unpaired sites and RNA16A for paired sites. 
AHMED M. et al., Revision of the genus Cobbionema (Nematoda, Selachinematidae)

Table 4. Species of the family Selachinematidae recorded from marine habitats in Sweden.

\begin{tabular}{ll}
\hline Species & Reference \\
\hline Choniolaimus crassus & Vitiello (1971) \\
Choniolaimus novempapillatus & Schuurmans Stekhoven (1946) \\
Choniolaimus panicus & Gerlach (1956) \\
Choniolaimus papillatus & Ditlevsen (1918) \\
Halichoanolaimus dolichurus & Ssaweljev (1912) \\
Halichoanolaimus filipjevi & Allgén (1953) \\
Halichoanolaimus norvegicus & Allgén (1940) \\
Halichoanolaimus robustus & Bastian (1865) \\
Latronema aberrans & Allgén (1934) \\
Gammanema rapax & Ssaweljev (1912) \\
Cobbionema acrocerca & Filipjev (1922) \\
Cobbionema cylindrolaimoides & Schuurmans Stekhoven (1950) \\
Cobbionema brevispicula sp. nov. & Current study \\
Cobbionema acuminata sp. nov. & Current study \\
Synonchiella microspiculoides & Schuurmans Stekhoven (1946) \\
Synonchiella riemanni & Warwick (1970) \\
\hline
\end{tabular}

specific features that would suggest their close relationship with Demonema. For example, all four species of Cobbionema examined in this study bear striking resemblances to Halichoanolaimus in their stoma morphology. The arrangement of the rhabdions appears as slightly to markedly modified forms of Halichoanolaimus. In several detailed illustrations of the posterior chamber of Halichoanolaimus (Gerlach 1964; Hasbrouck 1966; Belogurov \& Fadeeva 1980; Zograf et al. 2015), the rhabdions are seen as three in number, bifurcate anteriorly just as in Cobbionema. Demonema on the other hand has a stoma very similar to that of Cheironchus Cobb, 1917. The two, however, are placed in different clades in the 28S rRNA based phylogeny (Figs 12-13). Neither of the trees supported the monophyly of Choniolaiminae and Selachinematinae as subfamilies of Selachinematidae.

\section{Acknowledgements}

This research was supported by two grants from the Swedish Taxonomy Initiative: "Systematics of Swedish free-living nematodes of the orders Desmodorida and Araeolaimida" and "Systematics of poorly known marine nematodes of the class Chromadorea from Sweden". Sampling in the Skagerrak was conducted using vessels ("Skagerak", "Nereus" and "Oscar von Sydow") and facilities of the Sven Lovén Centre for Marine Sciences in Kristineberg and in Tjärnö. "Inventering Bratten" was an interdisciplinary inventory project which was also financially supported by the Swedish Taxonomy Initiative. Specimens of Demonema rapax used for sequencing were collected by Oleksandr Holovachov during the New Caledonia Hydrobiological expedition 2016-2018 (PI: Philippe Bouchet) which is a part of a cluster 
of expeditions under the "Our Planet Reviewed/La Planète revisitée" programme, implemented by the Muséum national d'histoire naturelle; Pascale Joannot, Head of expeditions programme) in partnership with the Conservatoire d'Espaces naturels, with funding from the Gouvernement de la NouvelleCalédonie, Province Sud, Province Nord, Office des Postes et Télécommunications, Maison de la Nouvelle-Calédonie and the French Ministry for the Overseas. The expedition operated under the permits issued by the Province Sud and the Province Nord, and the organisers thank, respectively, Emmanuel Coutures and Isabelle Jurquet (Province Sud) and Jean-Jérôme Cassan and Yannick Monlouis (Province Nord) for issuing of the permits. For logistics before, during, and after the field work, we thank Sébastien Faninoz and Alice Leblond. Our Planet Reviewed/La Planète revisitée is a global initiative founded in 2007 by the Muséum national d'histoire naturelle and Pro-Natura International. The senior author is grateful to Nicolas Charpin, Kaj Hnauane and Christine Pöllabauer for their invaluable assistance during 2017 and 2018 sampling trips.

\section{References}

Allgén C.A. 1934. Weitere Nematoden aus dem Öresund. Folia Zoologica et Hydrobiologica 7: 97-110.

Allgén C.A. 1940. Über enige norwegische marine Tiefen-Nematoden. Folia Zoologica et Hydrobiologica 10: $258-281$.

Allgén C.A. 1953. Revision der freilebenden marinen Nematoden aus der Umgebung der Staatlichen Zoologischen Station Kristeneberg an der Weskuste Schwedens. Zoologische Jahrbücher. Abteilung für Systematik, Ökologie und Geographie der Tiere 81: 548-603.

Bastian H.C. 1865. Monograph of the Anguillulidae, or Free Nematoids, Marine, Land, and Freshwater; with Descriptions of 100 New Species. The Transactions of the Linnean Society of London, vol. 25. https://doi.org/10.5962/bhl.title.14153

Bell T. \& Kramvis A. 2013. Fragment merger: an online tool to merge overlapping long sequence fragments. Viruses 5 (3): 824-833. https://doi.org/10.3390/v5030824

Belogurov N.P. \& Fadeeva O.I. 1980. Notes on the genus Halichoanolaimus (Nematoda, Choanolaimidae) with the description of two new species. Zoologicheskii Zhurnal 59 (5): 656-665.

Benson D.A., Cavanaugh M., Clark K., Karsch-Mizrachi I., Ostell J., Pruitt K.D. \& Sayers E.W. 2018. GenBank. Nucleic Acids Research 46 (D1): D41-D47. https://doi.org/10.1093/nar/gkx1094

Bezerra T.N., Decraemer W., Eisendle-Flöckner U., Hodda M., Holovachov O., Leduc D., Miljutin D., Mokievsky V., Peña Santiago R., Sharma J., Smol N., Tchesunov A., Venekey V., Zhao Z. \& Vanreusel A. 2020. Nemys: World Database of Nematodes. Available from http://nemys.ugent.be [accessed 4 Mar. 2020]. https://doi.org/10.14284/366

De Grisse A.T. 1969. Redescription ou modification de quelques techniques utilisés dans l'étude dęs nématodes phytoparaires. Mededelingen Rijksfakulteit Landbouwwetenschappen Gent 34: 351-369.

Derycke S., Remerie T., Vierstraete A., Backeljau T., Vanfleteren J., Vincx M. \& Moens T. 2005. Mitochondrial DNA variation and cryptic speciation within the free-living marine nematode Pellioditis marina. Marine Ecology Progress Series 300: 91-103. https://doi.org/10.3354/meps300091

Derycke S., De Ley P., Tandingan De Ley I., Holovachov O., Rigaux A. \& Moens T. 2010. Linking DNA sequences to morphology: cryptic diversity and population genetic structure in the marine nematode Thoracostoma trachygaster (Nematoda, Leptosomatidae). Zoologica Scripta 39 (3): 276-289. https://doi.org/10.1111/j.1463-6409.2009.00420.x

Ditlevsen H. 1918. Marine freeliving nematodes from Danish waters. Videnskabelige Meddelelser fra Dansk naturhistorisk Forening i Kjøbenhavn 7: 147-214. 
AHMED M. et al., Revision of the genus Cobbionema (Nematoda, Selachinematidae)

Filipjev I.N. 1922. New data about free-living nematodes of the Black Sea. Transactions of Stavropol Agricultural Institute 1: 83-42. [In Russian.]

Furstenberg J.P. \& Heyns J. 1987. Cobbionema capense n. sp. from Swartkops Estuary, Port Elizabeth (Nematoda: Selachinematidae). Canadian Journal of Zoology 65 (1): 80-82.

https://doi.org/10.1139/z87-012

Gerlach S.A. 1956. Diagnosen neuer Nematoden aus der Kieler Bucht. Kieler Meeresforschungen 12: 85-109.

Gerlach S.A. 1964. Revision der Choniolaiminae und Selachinematinae (freilebende MeeresNematoden). Mitteilungen aus dem Hamburgischen zoologischen Museum und Institut 61: 23-50.

Gerlach S.A. \& Riemann F. 1973. The Bremerhaven checklist of aquatic nematodes. A catalogue of nematoda Adenophorea excluding the Dorylaimida. Veröffentlichungen des Instituts für Meeresforschung in Bremerhaven Supplementband 4: 1-736.

Gowri-Shankar V. \& Jow H. 2006. PHASE: a software package for phylogenetics and sequence evolution. Available from http://www.bioinf.man.ac.uk/resources/phase/manual/ [accessed 22 Jul. 2020].

Hall T.A. 1999. BioEdit: a user-friendly biological sequence alignment editor and analysis program for Windows 95/98/NT. Nucleic Acids Symposium series 41: 95-98.

Hasbrouck E.R. 1966. Halichoanolaimus raritanensis n. sp. (Chromadoroidea: Cyatholaimidae) from New Jersey. Helminthological Society: 23-25.

Higgs P.G. 2000. RNA secondary structure: physical and computational aspects. Quarterly Reviews of Biophysics 33 (3): 199-253. https://doi.org/10.1017/S0033583500003620

Holovachov O., Camp L. \& Nadler S.A. 2015. Sensitivity of ribosomal RNA character sampling in the phylogeny of Rhabditida. Journal of Nematology 47 (4): 337-355.

Holovachov O., Haenel Q., Bourlat S.J. \& Jondelius U. 2017. Taxonomy assignment approach determines the efficiency of identification of OTUs in marine nematodes. Royal Society Open Science 4 (8): 170315. https://doi.org/10.1098/rsos.170315

Holterman M., van der WurffA., van den Elsen S., van Megen H., Bongers T., Holovachov O., Bakker J. \& Helder J. 2006. Phylum-wide analysis of SSU rDNA reveals deep phylogenetic relationships among nematodes and accelerated evolution toward crown clades. Molecular Biology and Evolution 23 (9): 1792-1800. https://doi.org/10.1093/molbev/ms1044

Hunt D.J. \& Palomares-Rius J.E. 2012. General morphology and morphometries of plant-parasitic nematodes. Practical Plant Nematology: 25-64.

Leduc D. 2013. Two new genera and five new species of Selachinematidae (Nematoda, Chromadorida) from the continental slope of New Zealand. European Journal of Taxonomy 63: 1-32.

https://doi.org/10.5852/ejt.2013.63

Maggenti A.R. 2005. Online Dictionary of Invertebrate Zoology.

Available from https://digitalcommons.unl.edu/ [accessed 22 Jul. 2020].

Miller M.A., Pfeiffer W. \& Schwartz T. 2010. Creating the CIPRES Science Gateway for inference of large phylogenetic trees. In: Gateway Computing Environments Workshop (GCE), 2010: 1-8.

https://doi.org/10.1109/gce.2010.5676129

Nunn G.B. 1992. Nematode molecular evolution: an investigation of evolutionary patterns among nematodes based upon DNA sequences. Ph.D. Thesis, University of Nottingham, UK. 
Schuurmans Stekhoven J.H.J. 1946. Freilebende marine Nematoden des Skagerraks und der Umgebung von Stocklholm. Arkiv för Zoologi 37A (16): 1-91.

Schuurmans Stekhoven J.H.J. 1950. The freeliving marine nemas of the Mediterranean: I. The Bay of Villefranche. Mémoires de l'Institut royal des Sciences naturelles de Belgique, deuxième série 37: 1220.

Seibel P.N., Müller T., Dandekar T., Schultz J. \& Wolf M. 2006. 4SALE - a tool for synchronous RNA sequence and secondary structure alignment and editing. BMC Bioinformatics 7 (1): 498.

https://doi.org/10.1186/1471-2105-7-498

Seinhorst J.W. 1959. A rapid method for the transfer of nematodes from fixative to anhydrous glycerin. Nematologica 4 (1): 67-69.

Ssaweljev S. 1912. Zur Kenntnis der freilebenden Nematoden des Kolafjords und des Relictensee Mogilnoje. Travaux de la Société Impériale des Naturalistes de Saint-Petersbourg 42: 108-126.

Stamatakis A. 2014. RAxML version 8: a tool for phylogenetic analysis and post-analysis of large phylogenies. Bioinformatics 30 (9): 1312-1313. https://doi.org/10.1093/bioinformatics/btu033

Tchesunov A.V 2014. Order Chromadorida Chitwood, 1933. In: Schmidt-Raesa A. (ed.) Handbook of Zoology, Gastrotricha, Cycloneuralia and Gnathifera. Volume 2: 373-398. De Gruyter, Hamburg. https://doi.org/10.1515/9783110274257.373

Vitiello P. 1971. Nématodes nouveaux des vases terrigènes cotières des côtes provençales. Téthys 2 (4): 859-875.

Zograf J., Trebukhova Y. \& Pavlyuk O. 2015. New deep-sea free-living marine nematodes from the Sea of Japan: the genera Siphonolaimus and Halichoanolaimus (Nematoda: Chromadorea) with keys to species identifications. Zootaxa 3911 (1): 63-80. https://doi.org/10.11646/zootaxa.3911.1.3

Manuscript received: 11 December 2019

Manuscript accepted: 18 May 2020

Published on: 14 August 2020

Topic editor: Rudy Jocqué

Desk editor: Pepe Fernández

Printed versions of all papers are also deposited in the libraries of the institutes that are members of the EJT consortium: Muséum national d'histoire naturelle, Paris, France; Meise Botanic Garden, Belgium; Royal Museum for Central Africa, Tervuren, Belgium; Royal Belgian Institute of Natural Sciences, Brussels, Belgium; Natural History Museum of Denmark, Copenhagen, Denmark; Naturalis Biodiversity Center, Leiden, the Netherlands; Museo Nacional de Ciencias Naturales-CSIC, Madrid, Spain; Real Jardín Botánico de Madrid CSIC, Spain; Zoological Research Museum Alexander Koenig, Bonn, Germany; National Museum, Prague, Czech Republic. 